\title{
New Ceratocystis species from Eucalyptus and Cunninghammia in South China
}

FeiFei Liu ${ }^{1,2} \cdot$ Michael Mbenoun $^{1} \cdot$ Irene Barnes $^{3} \cdot$ Jolanda Roux $^{1} \cdot$ Michael J.

Wingfield ${ }^{1} \cdot$ GuoQing $\mathrm{Li}^{2} \cdot$ JieQiong $\mathrm{Li}^{2} \cdot$ ShuaiFei Chen ${ }^{1,2}$

${ }^{1}$ Department of Microbiology and Plant Pathology, Forestry and Agricultural Biotechnology Institute (FABI), University of Pretoria, Private Bag X20, Pretoria 0028, South Africa

${ }^{2}$ China Eucalypt Research Centre (CERC), Chinese Academy of Forestry (CAF), ZhanJiang, 524022, GuangDong Province, China

${ }^{3}$ Department of Genetics, Forestry and Agricultural Research Institute (FABI), University of Pretoria, Private Bag X20, Pretoria 0028, South Africa

Corresponding author: ShuaiFei Chen, E-mail: shuaifei.chen@fabi.up.ac.za

Tel: +86-7593381022; Fax: +86-7593380674

Abstract During routine surveys for possible fungal pathogens in the rapidly expanding plantations of Eucalyptus and Cunninghamia lanceolata in China, numerous isolates of unknown species in the genus Ceratocystis (Microascales) were obtained from tree wounds. In this study we identified the Ceratocystis isolates from Eucalyptus and Cunninghamia in the GuangDong, GuangXi, FuJian and HaiNan Provinces of South China based on morphology and through comparisons of DNA sequence data for the ITS, partial $\beta$-tubulin and TEF-1 $\alpha$ gene regions. Morphological and DNA sequence comparisons revealed two previously unknown species residing in the Indo-Pacific Clade. These are described here as $C$. cercfabiensis sp. nov. and $C$. collisensis sp. nov. Isolates of $C$. cercfabiensis showed intragenomic variation in their ITS sequences and four strains were selected for cloning of the ITS gene region. Twelve ITS haplotypes were obtained from 17 clones selected for sequencing, 
differing in up to seven base positions and representing two separate phylogenetic groups. This is the first evidence of multiple ITS types in isolates of Ceratocystis residing in the Indo-Pacific Clade. Caution should thus be exercised when using the ITS gene region as a barcoding marker for Ceratocystis species in this clade. This study also represents the first record of a species of Ceratocystis from Cunninghamia.

Keywords Ceratocystidaceae $\cdot$ Fungal barcoding genes $\cdot$ Multiple ITS types $\cdot$ Plantation forestry

\section{Introduction}

The Ascomycete genus Ceratocystis (Microascales, Ceratocystidaceae), occurs on a wide range of hosts and has a wide global distribution (Harrington 2004; Roux and Wingfield 2009; De Beer et al. 2014). It was first characterized by Halsted (1890) to accommodate the causal agent of black rot on sweet potato and the type of the genus, Ceratocystis fimbriata. Species of Ceratocystis are characterised by dark, globoid ascomata with elongated necks, from which sticky ascospore masses exude at their apices (Upadhyay 1981). Most of the species in the genus, as defined recently by De Beer et al. (2014), are important pathogens of woody plants, including many agricultural, fruit and forest tree crops (Kile 1993; Roux and Wingfield 2009). These pathogens result in a multiplicity of symptoms such as branch and stem cankers, vascular staining, wilt, root rot, die-back, fruit rot and mortality (Kile 1993; Harrington 2004; Roux and Wingfield 2009).

The taxonomy of the genus Ceratocystis has been a source of confusion since the description of $C$. fimbriata by Halstead (1890). For many years Ceratocystis species and other genera in the Ceratocystidaceae were confused with fungi in the Ophiostomatales (Ophiostoma, Grosmannia, 
Ceratocystiopsis) due to similarities in their morphology (Wingfield et al. 1993, 2012). It was only with the advent of DNA sequence data that it was conclusively shown that these two groups represent multiple and distinct genera, and reside in separate families (Hausner et al. 1993; Zipfel et al. 2006). Most recently, species treated in the single genus Ceratocystis, but differing based on morphology, ecology and phylogenetic inference were re-classified in discrete genera (Wingfield et al. 2012; De Beer et al. 2014). Ceratocystis as it now stands represents a genus of mostly plant pathogens previously treated in the Ceratocystis fimbriata complex where species can be defined in the South American, African, Indo-Pacific and North American Clades (Johnson et al. 2005; Mbenoun et al. 2014). Others have been re-classified as species in the genera Ambrosiella, Chalaropsis, Davidsoniella, Endoconidiophora, Huntiella and Thielaviopsis (De Beer et al. 2014).

Despite recent advances in developing generic concepts for Ceratocystis, the taxonomy of some species in the genus remains unresolved. For example, the delimitation of species in the South American Clade lack sufficient markers for their clear delimitation (Al Adawi et al. 2013; Harrington et al. 2014; Fourie et al. 2015). The ITS region, which has been selected as the universal barcoding region for fungal species (Schoch et al. 2012), has been shown to be present as multiple ITS types in single isolates of some Ceratocystis species (Al Adawi et al. 2013; Naidoo et al. 2013; Harrington et al. 2014). It is hoped that with full genome sequences of representatives of each of these species (Wilken et al. 2013), and in some cases multiple species, robust and reliable taxonomic markers will be found to define species in the genus.

Several Ceratocystis species have been associated with serious diseases of trees in forests or grown in plantations or orchards. These have been treated in various previous studies (Roux et al. 2000, 2001; Harrington 2004; Tsopelas and Angelopoulos 2004; van Wyk et al. 2007a; Engelbrecht et al. 2007; Roux and Wingfield 2009; Li et al. 2014a, 2014b). Some examples include C. albifundus 
that causes a canker and wilt disease of Australian Acacia mearnsii trees in Africa (Morris et al. 1993; Roux et al. 2005), C. manginecans that causes a serious wilt of mango in Oman and Pakistan (van Wyk et al. 2007a), C. cacaofunesta that causes a lethal wilt disease of cacao (Theobroma cacao) in the Caribbean and Central and South America (Engelbrecht et al. 2007) and C. platani, that causes a canker stain and die-back of Platanus spp. in the USA and Europe (Tsopelas and Angelopoulos 2004). New Ceratocystis species, often associated with serious disease problems, are regularly being discovered and it can be argued that this group of fungi represent an assemblage of pathogens that are rapidly rising in importance globally.

During the past twenty years, the establishment of commercial forestry plantations has increased in China to meet the needs of a rapidly growing national economy. Plantations of both native and introduced tree species have been established across the country (Xie 2011). China is, for example, currently the third largest producer of Eucalyptus tree-products globally, with more than three and a half million hectares planted with this non-native tree species (Xie 2011). A similar situation is true for Cunninghamia lanceolata (Lamb.) Hook, which is native in China and is being used in large afforestation projects, particularly in southern China (Camille and Morrell 2006) and due to its rapid growth and naturally durable heartwood (Liu et al. 2010). Despite the growing importance of Eucalyptus and other plantation species in China, information regarding fungal diseases affecting these plantations is limited (Zhou and Wingfield 2011). This is also true regarding the possible occurrence and impact of Ceratocystis species associated with trees in these plantations, where there have been only two previous studies treating this topic (Chen et al. 2013; Li et al. 2014b).

In order to develop disease management strategies to ensure sustainable plantation forestry in China, an inventory of pathogenic and potentially pathogenic fungi on trees is being assembled. As part of this effort, the aim of this study was to identify Ceratocystis isolates obtained from freshly cut 
stumps or wounds in plantations of Eucalyptus species and Cunninghamia lanceolata growing in the GuangDong, GuangXi, FuJian and HaiNan Provinces of South China.

\section{Materials and methods}

Isolates

Ceratocystis species were isolated from wounds on Eucalyptus and Cunninghamia lanceolata in plantations in the GuangDong, GuangXi, FuJian and HaiNan Provinces of South China, between September 2013 and April 2014. Sampling was conducted at different sites from the stumps of recently (less than 1 month) harvested trees and fresh wounds on the branches and stems of trees. Ascomata of the fungi were identified by $10 \times$ magnification hand lens and samples of wood or bark bearing fresh fruiting bodies resembling those of Ceratocystis species were placed into individual paper bags and transported to the laboratory for isolation.

Samples were incubated in humid chambers at $25^{\circ} \mathrm{C}$ to induce sporulation. Single ascospore masses exuding from the tips of ascomata were transferred to $2 \%$ malt extract agar plates (MEA: 20 g/l malt extract, $20 \mathrm{~g} / \mathrm{l}$ agar, Biolab, Midrand, South Africa), containing $100 \mathrm{mg}$ streptomycin sulphate (Sigma, Steinheim, Germany) and incubated at $25^{\circ} \mathrm{C}$ for five to 10 days.

Representative isolates were deposited in the culture collection (CMW) of the Forestry and Agricultural Biotechnology Institute (FABI), University of Pretoria, South Africa (Table 1), and in the collection of the China Eucalypt Research Centre (CERC), Chinese Academy of Forestry (CAF), ZhanJiang, GuangDong Province, China. Representative isolates of all novel species were deposited 
with the Centraalbureau voor Schimmelcultures (CBS), Utrecht, Netherlands. Dried specimens of sporulating cultures were deposited with the National Collection of Fungi (PREM), Pretoria, South Africa.

Culture characteristics and morphology

All the fungal isolates collected in this study were grouped into morphotypes based on their characteristics in culture. Cultures were incubated on $2 \% \mathrm{MEA}$ at $25^{\circ} \mathrm{C}$ until sporulation and then grouped based on colour (Rayner 1970) and macro-morphology. To study the morphology of isolates, 3-week-old cultures representing each morphotype maintained at optimum growth temperature were used. Fruiting structures, including ascomata, ascospores, conidia and phialides from selected isolates were mounted in $80 \%$ lactic acid on microscope slides and examined under a Zeiss Axioskop microscope (Carl Zeiss, Germany). Fifty measurements of each morphological structure were made for the isolates chosen to represent the holotypes, and 10 measurements for each of the two additional isolates were selected to represent paratypes of the new species. Average (mean), standard deviation (std. dev.), minimum (min), and maximum (max) measurements were made and are presented as $[(\min -)($ mean - std. dev. $)-($ mean + std. dev. $)(-\max )]$ in the descriptions of the species.

Growth in culture

Three isolates (one holotype and two paratypes) of each of the new species found in this study were used for growth studies after 10 to 14 days of growth on $2 \%$ MEA. A $5 \mathrm{~mm}$ plug was removed from these cultures and transferred to the centres of $90 \mathrm{~mm}$ Petri dishes containing $2 \%$ MEA. These cultures were grown in the dark for 14 days at temperatures ranging from 10 to $35^{\circ} \mathrm{C}$ at five degree 
intervals. For each isolate and at each temperature, five replicate plates were prepared. Two diameter measurements, perpendicular to each other, were taken daily for each colony and the averages of diameter measurements for each temperature were computed. The entire experiment was repeated once.

DNA extraction, PCR and sequencing

For DNA sequencing, cultures of each isolate were grown on $2 \%$ MEA at $25^{\circ} \mathrm{C}$ for two weeks prior to DNA extraction. Mycelium was collected from the surface of cultures grown on MEA and transferred to Eppendorf tubes using a sterile scalpel. DNA extractions were made using the CTAB (cetyl trimethyl ammonium bromide) protocol (Möller et al. 1992). DNA working concentrations were adjusted to $\sim 100 \mathrm{ng} / \mu \mathrm{L}$, using a Thermo Scientific NanoDrop ${ }^{\circledR}$ ND-1000 Spectrophotometer (Nano Drop Technologies, Wilmington, DE, USA).

Three gene regions, namely the Internal Transcribed Spacer (ITS) regions (ITS1, ITS2) including the 5.8S rRNA gene, part of the Beta-tubulin 1 (BT1) and part of the Translation Elongation Factor-1 alpha (TEF-1 $\alpha$ ) regions were amplified using the Polymerase Chain Reaction (PCR). The ITS regions were amplified with primers ITS1 and ITS4 (White et al. 1990), the BT1 gene region using primers Bt1a and Bt1b (Glass and Donaldson 1995), and the TEF-1 $\alpha$ gene region with primers TEF1F and TEF2R (Jacobs et al. 2004).

For all gene regions, PCR reactions were conducted in a $25 \mu \mathrm{L}$ final volume. Each reaction comprised $2.5 \mu \mathrm{L}$ of $10 \times$ PCR buffer with $\mathrm{MgCl}_{2}(25 \mathrm{mM}), 0.2 \mu \mathrm{L}$ of Taq polymerase $(1 \mathrm{U} / \mu \mathrm{L})$ (Roche Diagnostic), $0.5 \mu \mathrm{L}$ of deoxynucleotide triphosphate (dNTPs) m ix (10 mM), $1 \mu \mathrm{L}$ of each primer $(10 \mathrm{mM})$ and $1 \mu \mathrm{L}$ of DNA template. Reactions were run on a Bio-Rad iCycler thermocycler 
(BIO-RAD, Hercules, CA, USA). For the ITS and BT1 gene regions, the thermal cycling conditions were the same and consisted of an initial denaturation step at $95^{\circ} \mathrm{C}$ for 5 min followed by 35 cycles of $30 \mathrm{~s}$ at $95^{\circ} \mathrm{C}, 45 \mathrm{~s}$ at $56^{\circ} \mathrm{C}$ and $60 \mathrm{~s}$ at $72^{\circ} \mathrm{C}$, with a final extension at $72^{\circ} \mathrm{C}$ for $10 \mathrm{~min}$. For the TEF-1 $\alpha$, the thermal cycling comprised an initial denaturation at $95^{\circ} \mathrm{C}$ for $5 \min$ followed by 10 primary amplification cycles of $30 \mathrm{~s}$ at $95^{\circ} \mathrm{C}, 30 \mathrm{~s}$ at $56^{\circ} \mathrm{C}$, and $60 \mathrm{~s}$ at $72^{\circ} \mathrm{C}$, then 30 additional cycles of the same reaction sequence, with a $5 \mathrm{~s}$ increase in the annealing step per cycle. Reactions were completed with a final extension at $72^{\circ} \mathrm{C}$ for $10 \mathrm{~min}$. Amplification was confirmed by staining PCR products ( $3 \mu \mathrm{L}$ aliquots) with $1.5 \mu \mathrm{L}$ of GelRed ${ }^{\mathrm{TM}}$ Nucleic Acid Gel stain (Biotium, Hayward, CA, USA), and separating them on a $2 \%$ agarose gel, followed by visualization under UV light. PCR products were purified by filtration using $6 \%$ Sephadex G-50 (Sigma).

Forward and reverse sequencing reactions were performed in $12 \mu \mathrm{L}$ final volumes with the same primers as used for the PCR reactions. The mixtures contained $1 \mu \mathrm{L}$ BigDye ${ }^{\circledR}$ Terminator v. 3.1 ready reaction mixture (Perkin-Elmer, Warrington, UK), $2 \mu \mathrm{L}$ sequencing buffer, $1 \mu \mathrm{L}$ of either the forward or reverse primer $(10 \mathrm{mM})$ for each gene region or $2 \mu \mathrm{L}$ cleaned PCR product. The thermal cycling conditions comprised 25 cycles of $10 \mathrm{~s}$ at $96^{\circ} \mathrm{C}, 5 \mathrm{~s}$ at $54^{\circ} \mathrm{C}$ and 4 min at $60^{\circ} \mathrm{C}$. Sequencing products were cleaned using Sephadex G-50 columns and dried in an Eppendorf 5301 vacuum concentrator, at $60^{\circ} \mathrm{C}$ for 5 min. They were thereafter run on an ABI PRISM ${ }^{\mathrm{TM}} 3100$ DNA Analyzer (Applied BioSystems, Foster City, CA, USA).

Cloning

Some Ceratocystis strains that showed ambiguity in the sequences of the ITS region were cloned using the $\mathrm{pGEM}^{\circledR}-\mathrm{T}$ and $\mathrm{pGEM}^{\circledR}{ }^{\circledR} \mathrm{T}$ Easy Vector System (Promega, Madison, USA) cloning kit, following the manufacturer's instructions. The primers T7 and SP6 were used for amplification and 
sequencing (Invitrogen, Life technologies, Johannesburg, SA). For each ambiguous PCR product, up to five clones were sequenced. The amplification reaction mixture had a total volume of $25 \mu \mathrm{L}$, consisting of $5 \mu \mathrm{L} 5 \times$ MyTaq $^{\mathrm{TM}}$ Buffer (comprise $5 \mathrm{mM}$ dNTPs, $15 \mathrm{mM} \mathrm{MgCl}_{2}$ ), $0.5 \mu \mathrm{L} \mathrm{MyTaq}^{\mathrm{TM}}$ DNA Polymerase (Bioline Ltd.UK), $1 \mu \mathrm{L}$ DNA, $1 \mu \mathrm{L}$ of each primer $(10 \mathrm{mM})$ and distilled $\mathrm{H}_{2} \mathrm{O}$. The PCR cycler program consisted of $95^{\circ} \mathrm{C}$ for 5 min followed by 35 cycles of $95^{\circ} \mathrm{C}$ for $30 \mathrm{~s}, 56^{\circ} \mathrm{C}$ for $30 \mathrm{~s}, 72^{\circ} \mathrm{C}$ for $1 \mathrm{~min}$ and a final extension of $72^{\circ} \mathrm{C}$ for $10 \mathrm{~min}$.

Multi-gene phylogenetic analyses

A preliminary identity for the Ceratocystis isolates was obtained by performing a similarity search (standard nucleotide BLAST) of the ITS, BT1 and TEF-1 $\alpha$ sequences against the GenBank nucleotide database (http://www.ncbi.nlm.nih.gov). Sequences for closely related type cultures of Ceratocystis species were downloaded from GenBank to compile datasets for the phylogenetic analyses (Table 1). Individual data sets and a combined data set of the BT1 and TEF-1a gene regions were used for phylogenetic analyses. Since multiple ITS copies occurred in some isolates, this dataset was not combined with the other gene regions in the analyses.

Sequences for each of the three gene regions were aligned using the online interface of MAFFT v. 7 (http://mafft.cbrc.jp/alignment/server) (Katoh et al. 2002), with the iterative refinement method (FFT-NS-i settings) selected. Sequence alignments were edited manually in MEGA v. 6 (Tamura et al. 2007). Sequence alignments for all the datasets were deposited in TreeBASE (http://treebase.org/treebase-web) and sequences for the novel taxa deposited in GenBank (Table 1).

Two different phylogenetic analyses methods were used for each of the datasets and for the combined BT1 and TEF-1a dataset. Maximum parsimony (MP) analyses were performed using 
Table 1 List of Ceratocystis isolates used in this study

\begin{tabular}{|c|c|c|c|c|c|c|c|c|c|}
\hline \multirow[t]{2}{*}{ Species } & \multirow[t]{2}{*}{ CMW No. ${ }^{1}$} & \multirow[t]{2}{*}{ CERC No. ${ }^{1,2}$} & \multirow[t]{2}{*}{ Other no. ${ }^{1}$} & \multicolumn{3}{|c|}{ GenBank accession no. } & \multirow[t]{2}{*}{ Hosts (or substrate) } & \multirow[t]{2}{*}{ Collectors } & \multirow[t]{2}{*}{ Geogrophic Origin } \\
\hline & & & & ITS $^{3}$ & $\beta$-tubulin & TEF-1a & & & \\
\hline C. albifundus & CMW4068 & & & DQ520638 & EF070429 & EF070400 & Acacia mearnsii & J. Roux & South Africa \\
\hline C. albifundus & CMW5329 & & & AF388947 & DQ371649 & EF070401 & A. mearnsii & J. Roux & Uganda \\
\hline C. atrox & CMW19383 & & CBS 120517 & EF070414 & EF070430 & EF070402 & Eucalyptus grandis & M.J. Wingfield & Australia \\
\hline C. atrox & CMW19385 & & CBS 120518 & EF070415 & EF070431 & EF070403 & E. grandis & M.J. Wingfield & Australia \\
\hline C. cercfabiensis & CMW42489 & CERC2168 & & N/A & KP727605 & KP727630 & Eucalyptus sp. & S.F. Chen \& F.F. Liu & HaiNan, China \\
\hline C. cercfabiensis & CMW43029 9 & CERC2170 & CBS 139654 & See Table 3 & KP727618 & KP727643 & Eucalyptus sp. & S.F. Chen \& F.F. Liu & HaiNan, China \\
\hline C. cercfabiensis & CMW42504 & CERC2323 & & N/A & KP727595 & KP727620 & Eucalyptus sp. & S.F. Chen \& F.F. Liu & GuangXi, China \\
\hline C. cercfabiensis & CMW43030 & CERC2325 & & N/A & KP727606 & KP727631 & Eucalyptus sp. & S.F. Chen \& F.F. Liu & GuangXi, China \\
\hline C. cercfabiensis & CMW42512 & CERC2335 & & See Table 3 & KP727607 & KP727632 & Eucalyptus sp. & S.F. Chen \& F.F. Liu & GuangXi, China \\
\hline C. cercfabiensis & CMW42515 4,5 & CERC2345 & CBS 139655 & N/A & KP727596 & KP727621 & Eucalyptus sp. & S.F. Chen \& F.F. Liu & GuangXi, China \\
\hline C. cercfabiensis & CMW43033 & CERC2471 & & N/A & KP727597 & KP727622 & Eucalyptus sp. & S.F. Chen \& F.F. Liu & FuJian, China \\
\hline C. cercfabiensis & CMW42574 & CERC2549 & & N/A & KP727598 & KP727623 & Eucalyptus sp. & S.F. Chen \& F.F. Liu & GuangDong, China \\
\hline C. cercfabiensis & CMW42577 & CERC2552 & & N/A & KP727599 & KP727624 & Eucalyptus sp. & S.F. Chen \& F.F. Liu & GuangDong, China \\
\hline C. cercfabiensis & CMW42736 ${ }^{5,6}$ & CERC2576 & & See Table 3 & KP727600 & KP727625 & Eucalyptus sp. & S.F. Chen \& F.F. Liu & GuangDong, China \\
\hline C. cercfabiensis & CMW42741 & CERC2581 & & See Table 3 & KP727601 & KP727626 & Eucalyptus sp. & S.F. Chen \& F.F. Liu & GuangDong, China \\
\hline C. cercfabiensis & CMW42745 & CERC2586 & & N/A & KP727608 & KP727633 & Eucalyptus sp. & S.F. Chen \& F.F. Liu & GuangDong, China \\
\hline C. cercfabiensis & CMW42790 & CERC2646 & & N/A & KP727602 & KP727627 & Eucalyptus sp. & S.F. Chen \& F.F. Liu & GuangXi, China \\
\hline C. cercfabiensis & CMW42794 & CERC2686 & & N/A & KP727609 & KP727634 & Eucalyptus sp. & S.F. Chen \& F.F. Liu & GuangDong, China \\
\hline C. cercfabiensis & CMW42795 & CERC2687 & CBS 139656 & N/A & KP727619 & KP727644 & Eucalyptus sp. & S.F. Chen \& F.F. Liu & GuangDong, China \\
\hline C. cercfabiensis & CMW42803 & CERC2800 & & N/A & KP727603 & KP727628 & Eucalyptus sp. & S.F. Chen \& F.F. Liu & GuangXi, China \\
\hline C. cercfabiensis & CMW42812 & CERC2817 & & N/A & KP727604 & KP727629 & Eucalyptus sp. & S.F. Chen \& F.F. Liu & GuangXi, China \\
\hline C. collisensis & CMW43031 & CERC2456 & & KP727575 & KP727612 & KP727637 & Cunninghamia lanceolata & S.F. Chen \& F.F. Liu & FuJian, China \\
\hline C. collisensis & CMW42550 & CERC2457 & & KP727576 & KP727613 & KP727638 & C. lanceolata & S.F. Chen \& F.F. Liu & FuJian, China \\
\hline C. collisensis & CMW42551 $^{5}$ & CERC2458 & & KP727577 & KP727610 & KP727635 & C. lanceolata & S.F. Chen \& F.F. Liu & FuJian, China \\
\hline C. collisensis & CMW42552 4,5 & CERC2459 & CBS 139679 & KP727578 & KP727614 & KP727639 & C. lanceolata & S.F. Chen \& F.F. Liu & FuJian, China \\
\hline C. collisensis & CMW42553 ${ }^{4,5}$ & CERC2465 & CBS 139646 & KP727579 & KP727611 & KP727636 & C. lanceolata & S.F. Chen \& F.F. Liu & FuJian, China \\
\hline C. collisensis & CMW42554, & CERC2466 & CBS 139647 & KP727580 & KP727615 & KP727640 & C. lanceolata & S.F. Chen \& F.F. Liu & FuJian, China \\
\hline C. collisensis & CMW43032 & CERC2467 & & KP727581 & KP727616 & KP727641 & C. lanceolata & S.F. Chen \& F.F. Liu & FuJian, China \\
\hline C. collisensis & CMW42555 & CERC2468 & & KP727582 & KP727617 & KP727642 & C. lanceolata & S.F. Chen \& F.F. Liu & FuJian, China \\
\hline C. corymbiicola & CMW29120 & & CBS 127215 & HM071902 & HM071914 & HQ236453 & Corymbia variegata & G.K. Nkuekam & Australia \\
\hline C. corymbiicola & CMW29349 & & CBS 127216 & HM071919 & HQ236455 & HМ071905 & Eucalyptus pilularis & G.K. Nkuekam & Australia \\
\hline C. larium & CMW25434 & & CBS 122512 & EU881906 & EU881894 & EU881900 & Styrax benzoin & M.J. Wingfield & Indonesia \\
\hline C. larium & CMW25435 & & CBS 122606 & EU881907 & EU881895 & EU881901 & S. benzoin & M.J. Wingfield & Indonesia \\
\hline C. obpyriformis & CMW23807 & & CBS 122608 & EU245004 & EU244976 & EU244936 & Acacia mearnsii & R.N. Heath & South Africa \\
\hline
\end{tabular}


${ }^{1} \mathrm{CMW}=$ Culture collection of the Forestry and Agricultural Biotechnology Institute (FABI), University of Pretoria, Pretoria, South Africa;

CERC $=$ Culture collection of China Eucalypt Research Centre (CERC), Chinese Academy of Forestry (CAF), ZhanJiang, GuangDong

Province, China; $\mathrm{CBS}=$ the Centraalbureau voor Schimmelcultures, Utrecht, The Netherlands

${ }^{2}$ Isolates indicated in bold are newly described in this study

${ }^{3}$ NA (not applicable) indicates isolates where multiple ITS types exist for species of $C$. cercfabiensis and where a single clean ITS sequence could not be obtained without first cloning

${ }^{4}$ Isolates used for the growth study

${ }^{5}$ Isolates obtained and used in the phylogenetic analyses

${ }^{6}$ Isolates used for the ITS cloning 
PAUP v. 4.0b10 (Swofford 2002) and maximum likelihood (ML) tests were conducted with PhyML v. 3.0 (Guindon and Gascuel 2003). For MP analyses, gaps were treated as a fifth character and the characters were unordered and of equal weight with 1000 random addition replicates. A partition homogeneity test (PHT) was used to determine the congruence of the BT1 and TEF-1a datasets. For the analyses of each dataset, the most parsimonious trees were obtained with the heuristic search function and tree bisection and reconstruction (TBR) as branch swapping algorithms. MAXTREES were unlimited and branch lengths of zero were collapsed. A bootstrap analysis (50\% majority rule, 1000 replicates) was done to determine the confidence levels of the tree-branching points (Felsenstein 1985). Tree length (TL), consistency index (CI), retention index (RI) and the homoplasy index (HI) were used to assess the trees (Hillis and Huelsenbeck 1992).

For ML (maximum likelihood) analysis of each dataset, the best models of nucleotide substitution were determined with Modeltest v. 3.7 (Posada and Crandall 1998). The analyses were conducted with PhyML v. 3.0 (Guindon and Gascuel 2003). Parameters in PhyML included the retention of the maximum number of 1000 trees and the determination of nodal support by non-parametric bootstrapping with 1000 replicates. The phylogenetic trees were viewed using MEGA v.6 (Tamura et al. 2007). For both MP and ML analyses, Davidsoniella virescens (CMW11164) was used as the outgroup taxon (Table 2). 
Table 2 Statistics resulting from phylogenetic analyses

\begin{tabular}{lllllllll}
\hline & & \multicolumn{5}{c}{ Maximum parsimony } \\
\cline { 6 - 9 } Dataset & No. of taxa & No. of bp ${ }^{1}$ & PIC $^{2}$ & Number trees & Tree length & CI $^{3}$ & RI $^{4}$ & HI $^{5}$ \\
\hline ITS & 35 & 553 & 228 & 3 & 499 & 0.858 & 0.945 & 0.142 \\
BT1 & 27 & 534 & 85 & 7 & 214 & 0.888 & 0.933 & 0.112 \\
TEF-1a & 27 & 701 & 83 & 6 & 281 & 0.9 & 0.909 & 0.099 \\
BT1/TEF-1a & 27 & 1235 & 168 & 2 & 501 & 0.884 & 0.912 & 0.116 \\
\hline
\end{tabular}

\begin{tabular}{llllll}
\hline & \multicolumn{5}{c}{ Maximum likelihood } \\
\cline { 2 - 6 } Dataset & Subst model $^{6}$ & NST $^{7}$ & Rate matrix & Ti/tv ratio $^{8}$ & Rates $^{9}$ \\
\hline ITS & HKY+G & 2 & & 1.3092 & gamma \\
BT1 & TrN+I & 6 & 1.00002 .40231 .00001 .00004 .9894 & equal \\
TEF-1a & TrNef+G & 6 & 1.00001 .53581 .00001 .00003 .7338 & gamma \\
BT1/TEF-1a & TrN+G & 6 & 1.00001 .87941 .00001 .00004 .1007 & gamma \\
\hline
\end{tabular}

\footnotetext{
${ }^{1} \mathrm{bp}=$ base pairs. ${ }^{2} \mathrm{PIC}=$ number of parsimony informative characters. ${ }^{3} \mathrm{CI}=$ consistency index. ${ }^{4} \mathrm{RI}=$ retention index. ${ }^{5}$ $\mathrm{HI}=$ homoplasy index. ${ }^{6}$ Subst. model $=$ best fit substitution model. ${ }^{7}$ NST $=$ number of substitution rate categories. ${ }^{8}$ $\mathrm{Ti} / \mathrm{TV}$ ratio $=$ transition/transversion ratio. ${ }^{9} \mathrm{I}=$ proportion of invariable sites
}

\section{Results}

Isolates

A total of 180 isolates resembling species of Ceratocystis were obtained from 30 different trees in 13 different forestry plantations (Fig. 1), including 11 Eucalyptus plantations and two Cunninghamia lanceolata plantations in the GuangDong, GuangXi, HaiNan and FuJian Provinces in South China. Ceratocystis ascocarps were commonly found on the stumps and branch/stem wounds. Slight discolouration was observed on the wood where fruiting bodies were present.

Isolates could be assigned to two broad groups based on culture morphology and the appearance of the fruiting bodies produced on MEA. One group, comprising the majority of isolates (172), had a strong fruity (banana) odour. These isolates produced sexual fruiting structures abundantly in culture. All isolates had dark, globoid ascomata with necks $\sim 1100 \mu \mathrm{m}$ in length and they produced 


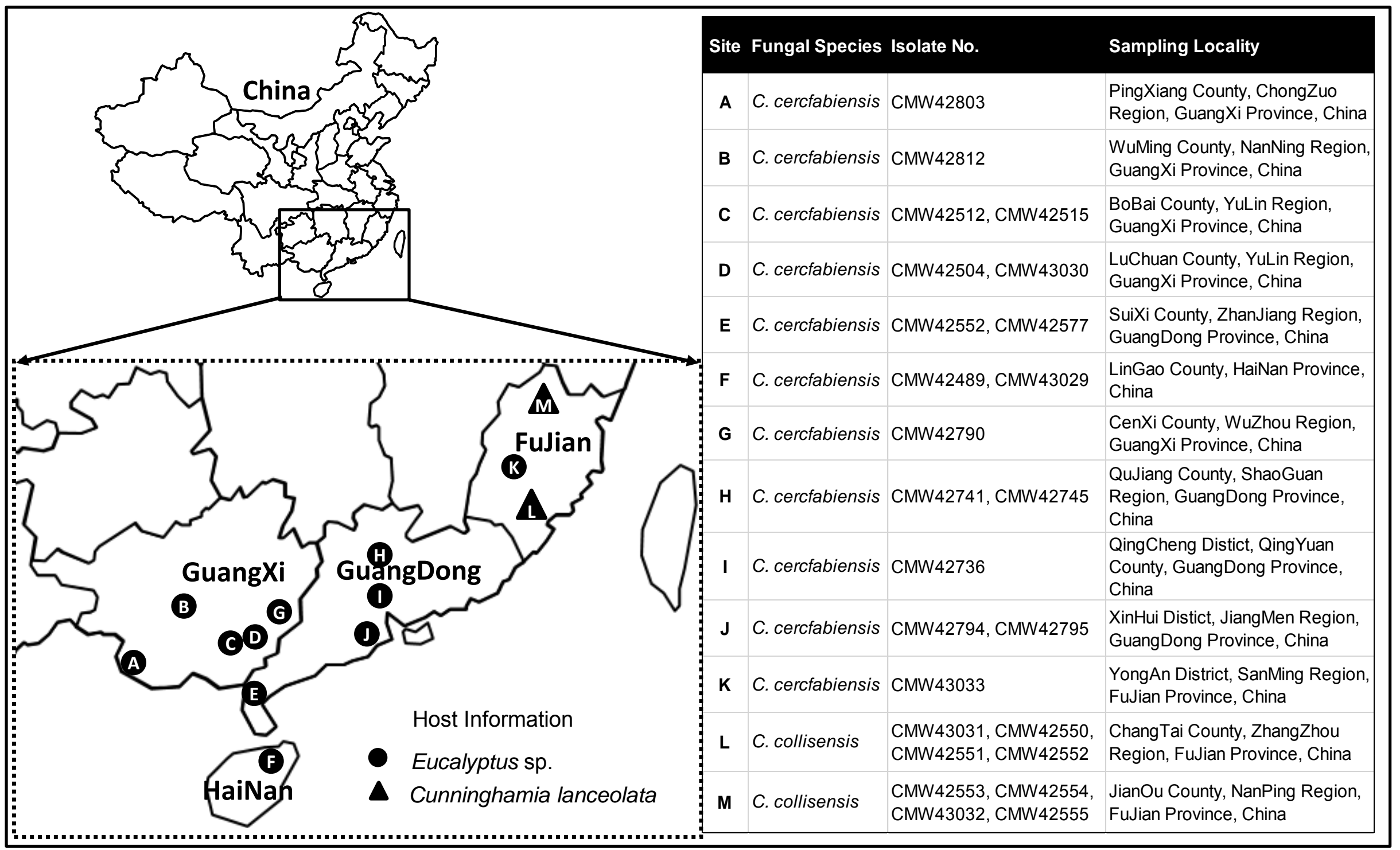

Fig. 1 Distribution of Ceratocystis cercfabiensis and C. collisensis in South China 
hat-shaped, sheathed ascospores. Only flask-shaped conidiophore producing bacilliform, hyaline conidia were found and broader conidiophores producing barrel-shaped conidia appeared to be absent for isolates in this group. All isolates in this group were from Eucalyptus trees.

Eight isolates were collected from two $C$. lanceolata trees. These isolates were slower growing than those from Eucalyptus and had an irregular colony shape in culture. Limited numbers of ascomata were produced by these isolates. Ascomata were dark and globoid but with much shorter necks $(\sim 300 \mu \mathrm{m})$ than the Eucalyptus isolates and they produced hat-shaped, sheathed ascospores. Both bacilliform and barrel-shaped conidia were observed and these isolates from C. lanceolata also produced dark aleurioconidia in chains.

DNA extraction, PCR and sequencing

Twenty eight isolates were selected for DNA sequencing. These included all eight isolates from $C$. lanceolata and 20 from Eucalyptus species. Care was taken to select isolates representing each of the different sampling sites. PCR produced fragments of $\sim 550 \mathrm{bp}$ in length for the ITS, $\sim 530 \mathrm{bp}$ for the BT1 and $~ 700$ bp for the TEF-1a gene regions.

The PCR amplification of the ITS gene region for some of the Eucalyptus isolates showed intragenomic variation in sequences. The sequence chromatograms of the ITS region for these isolates showed clear peaks up to $\sim 140 \mathrm{bp}$ and after that the base calling revealed conflicting sequence data (Fig. 2). Four strains (CMW43029, CMW42512, CMW42736 and CMW42741) that had conflicting ITS sequences were selected for cloning. 


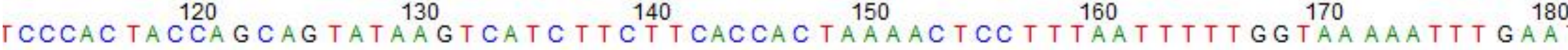

130

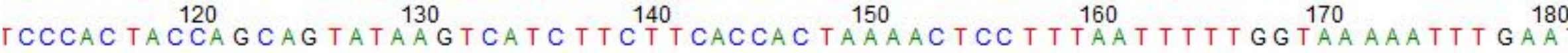

150

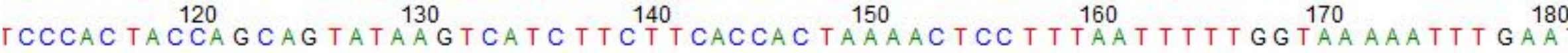

170

\section{A}

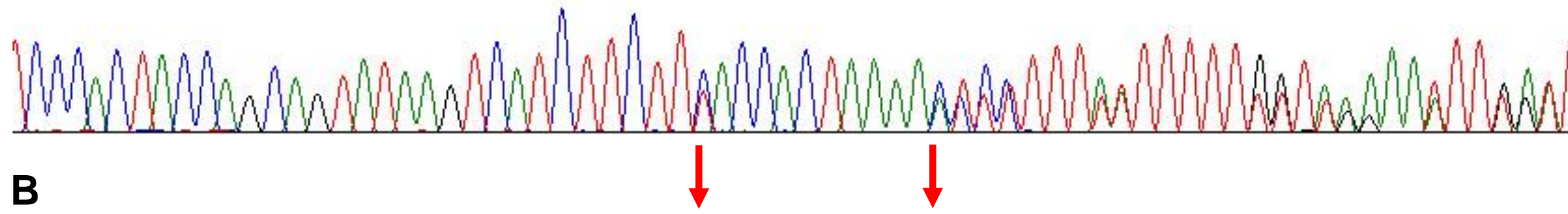

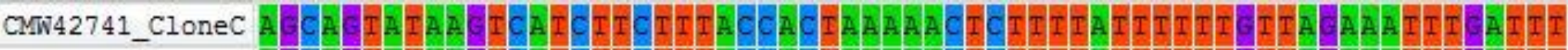

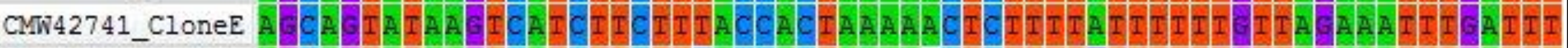

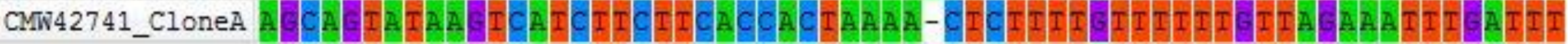

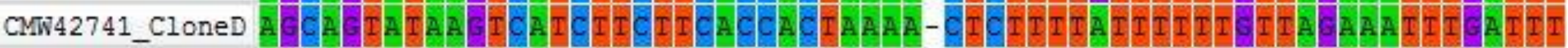

CMW42741_CloneG AGCAGIATAAGICATCIICIICACCACIAAAA-CICIIITAIIIIIIIIAIIA_AAAIIICAIIT

Fig. 2 Partial chromatogram of the ITS region of an isolate from Ceratocystis cercfabiensis. A) A good quality sequence up to 140 bp after which there was conflict in the base calling. This is a clear illustration of the presence of more than one ITS type in a single isolate. B) Sequence data from the cloned sequences show that the presence of a single nucleotide indel (indicated by the arrow) resulted in a frame shift of the downstream sequence in the one ITS type 
Cloning

PCR amplification of the cloned ITS sequences produced fragment sizes of about $1000 \mathrm{bp}$ and the sequence reactions for these amplicons resulted in clear, readable chromatograms. Twelve ITS haplotypes were obtained for the 17 sequenced clones derived from the four isolates studied. These haplotypes differed at up to seven base positions (Table 3, Fig. 2), and represented two separate phylogenetic groups when analysed using PAUP v. 4.0b10. This is typical of Ceratocystis species that have multiple ITS types (Al Adawi et al. 2013; Naidoo et al. 2013).

Multi-gene phylogenetic analyses

All sequences obtained for the Ceratocystis isolates in this study were deposited in GenBank (Table 1). The BLAST search results using the NCBI nucleotide database showed that the Ceratocystis isolates from China resided in two distinct groups: one from Eucalyptus, the other from $C$. lanceolata. Isolates from Eucalyptus were most similar to C. corymbiicola, C. polychroma and $C$. atrox, and those from $C$. lanceolata most similar to $C$. larium, both residing in the Indo-Pacific clade defined for the genus.

The partition homogeneity test (PHT) comparing the BT1 and TEF-1a gene datasets gave a PHT value of $\mathrm{P}=0.005$ showing that the data for these two gene regions could be combined for the phylogenetic analyses (Cunningham 1997). The aligned sequences for the ITS (35 taxa, 553 characters), BT1 (27 taxa, 534 characters), TEF-1 $\alpha$ (27 taxa, 701 characters), and the combined BT1 and TEF-1 $\alpha$ (27 taxa, 1235 characters) datasets were deposited in TreeBASE (No. S17259). Statistical values for the resultant phylogenetic trees for the maximum parsimony analyses and parameters for the best fit substitution models of maximum likelihood are provided in Table 2 . 
Table 3 Nucleotide differences observed in the ITS region between the cloned sequences in four isolates of Ceratocystis cercfabiensis $^{1}$

\begin{tabular}{|c|c|c|c|c|c|c|c|c|c|c|c|c|c|c|c|c|c|c|}
\hline \multirow{2}{*}{ Isolate No. } & \multirow{2}{*}{ Clone No. } & \multirow{2}{*}{$\begin{array}{l}\text { Clone } \\
\text { type }\end{array}$} & \multirow{2}{*}{$\begin{array}{c}\text { GenBank } \\
\text { accession no. }\end{array}$} & \multicolumn{15}{|c|}{ ITS } \\
\hline & & & & 28 & 41 & 64 & 86 & 148 & 155 & 167 & 226 & 302 & 310 & 325 & 396 & 448 & 491 & 527 \\
\hline \multirow[t]{4}{*}{ CMW42736 } & CMW42736_Clone A & 1 & KP727583 & $\mathrm{A}$ & $\mathrm{G}$ & $\mathrm{G}$ & G & $\mathrm{C}$ & - & A & $\mathrm{T}$ & $\mathrm{T}$ & A & $\mathrm{A}$ & $\mathrm{T}$ & $\mathrm{T}$ & $\mathrm{T}$ & $\mathrm{C}$ \\
\hline & CMW42736_Clone E & 1 & NA & A & $\mathrm{G}$ & $\mathrm{G}$ & G & $\mathrm{C}$ & - & A & $\mathrm{T}$ & $\mathrm{T}$ & A & A & $\mathrm{T}$ & $\mathrm{T}$ & $\mathrm{T}$ & $\mathrm{C}$ \\
\hline & CMW42736_Clone B & 2 & KP727584 & $\mathrm{A}$ & A & A & $\mathrm{G}$ & $\mathrm{T}$ & A & A & $\mathrm{T}$ & $\mathrm{T}$ & A & A & - & $\mathrm{C}$ & $\mathrm{T}$ & $\mathrm{C}$ \\
\hline & CMW42736_Clone D & 3 & KP727585 & A & G & $\mathrm{G}$ & G & $\mathrm{C}$ & - & A & $\mathrm{T}$ & $\mathrm{T}$ & A & A & $\mathrm{T}$ & $\mathrm{T}$ & $\mathrm{C}$ & $\mathrm{C}$ \\
\hline \multirow[t]{5}{*}{ CMW42741 } & CMW42741_Clone A & 4 & KP727586 & $\mathrm{A}$ & $\mathrm{G}$ & $\mathrm{G}$ & $\mathrm{G}$ & $\mathrm{C}$ & - & G & $\mathrm{T}$ & $\mathrm{T}$ & A & A & $\mathrm{T}$ & $\mathrm{T}$ & $\mathrm{T}$ & $\mathrm{C}$ \\
\hline & CMW42741_Clone C & 5 & NA & $\mathrm{A}$ & A & A & G & $\mathrm{T}$ & $\mathrm{A}$ & A & $\mathrm{T}$ & $\mathrm{T}$ & A & A & - & $\mathrm{C}$ & $\mathrm{T}$ & - \\
\hline & CMW42741_Clone E & 5 & KP727588 & $\mathrm{A}$ & A & A & $\mathrm{G}$ & $\mathrm{T}$ & A & A & $\mathrm{T}$ & $\mathrm{T}$ & A & A & - & $\mathrm{C}$ & $\mathrm{T}$ & - \\
\hline & CMW42741_Clone D & 6 & KP727587 & A & $\mathrm{G}$ & $\mathrm{G}$ & $\mathrm{G}$ & $\mathrm{C}$ & - & A & $\mathrm{T}$ & $\mathrm{T}$ & A & G & $\mathrm{T}$ & $\mathrm{T}$ & $\mathrm{T}$ & $\mathrm{C}$ \\
\hline & CMW42741_Clone G & 6 & NA & A & G & $\mathrm{G}$ & $\mathrm{G}$ & $\mathrm{C}$ & - & A & $\mathrm{T}$ & $\mathrm{T}$ & A & G & $\mathrm{T}$ & $\mathrm{T}$ & $\mathrm{T}$ & $\mathrm{C}$ \\
\hline \multirow[t]{5}{*}{ CMW42512 } & CMW42512_Clone C & 1 & NA & $\mathrm{A}$ & $\mathrm{G}$ & $\mathrm{G}$ & $\mathrm{G}$ & $\mathrm{C}$ & - & A & $\mathrm{T}$ & $\mathrm{T}$ & A & A & $\mathrm{T}$ & $\mathrm{T}$ & $\mathrm{T}$ & $\mathrm{C}$ \\
\hline & CMW42512_Clone D & 1 & NA & $\mathrm{A}$ & $\mathrm{G}$ & $\mathrm{G}$ & $\mathrm{G}$ & $\mathrm{C}$ & - & A & $\mathrm{T}$ & $\mathrm{T}$ & A & A & $\mathrm{T}$ & $\mathrm{T}$ & $\mathrm{T}$ & $\mathrm{C}$ \\
\hline & CMW42512_Clone E & 7 & KP727589 & $\mathrm{A}$ & $\mathrm{G}$ & $\mathrm{G}$ & $\mathrm{G}$ & $\mathrm{C}$ & A & A & $\mathrm{T}$ & $\mathrm{T}$ & A & A & $\mathrm{T}$ & $\mathrm{T}$ & $\mathrm{T}$ & - \\
\hline & CMW42512_Clone G & 8 & KP727590 & A & $\mathrm{G}$ & $\mathrm{G}$ & G & $\mathrm{C}$ & A & A & $\mathrm{C}$ & $\mathrm{T}$ & A & A & $\mathrm{T}$ & $\mathrm{T}$ & $\mathrm{T}$ & - \\
\hline & CMW42512_Clone H & 9 & KP727591 & $\mathrm{A}$ & A & $\mathrm{G}$ & - & $\mathrm{C}$ & A & A & $\mathrm{T}$ & $\mathrm{T}$ & A & A & $\mathrm{T}$ & $\mathrm{T}$ & $\mathrm{T}$ & $\mathrm{C}$ \\
\hline \multirow[t]{3}{*}{ CMW43029 } & CMW43029_Clone F & 10 & KP727592 & A & G & $\mathrm{G}$ & $\mathrm{G}$ & $\mathrm{C}$ & A & A & $\mathrm{T}$ & $\mathrm{C}$ & A & A & $\mathrm{T}$ & $\mathrm{T}$ & $\mathrm{T}$ & - \\
\hline & CMW43029_Clone G & 11 & KP727593 & $\mathrm{A}$ & $\mathrm{G}$ & $\mathrm{G}$ & G & $\mathrm{C}$ & - & A & $\mathrm{T}$ & $\mathrm{T}$ & G & $\mathrm{A}$ & $\mathrm{T}$ & $\mathrm{T}$ & $\mathrm{T}$ & $\mathrm{C}$ \\
\hline & CMW43029_Clone K & 12 & KP727594 & $\mathrm{G}$ & G & $\mathrm{G}$ & $\mathrm{G}$ & $\mathrm{C}$ & - & A & $\mathrm{T}$ & $\mathrm{T}$ & A & A & $\mathrm{T}$ & $\mathrm{T}$ & $\mathrm{T}$ & $\mathrm{C}$ \\
\hline CMW42515 & NA & 5 & NA & A & A & A & G & $\mathrm{T}$ & A & A & $\mathrm{T}$ & $\mathrm{T}$ & A & A & - & $\mathrm{C}$ & $\mathrm{T}$ & - \\
\hline CMW42795 & NA & 1 & NA & A & G & $\mathrm{G}$ & $\mathrm{G}$ & $\mathrm{C}$ & - & A & $\mathrm{T}$ & $\mathrm{T}$ & A & A & $\mathrm{T}$ & $\mathrm{T}$ & $\mathrm{T}$ & $\mathrm{C}$ \\
\hline
\end{tabular}

${ }^{1}$ Nucleotides that are different from the majority consensus sequence are highlighted in grey blocks 


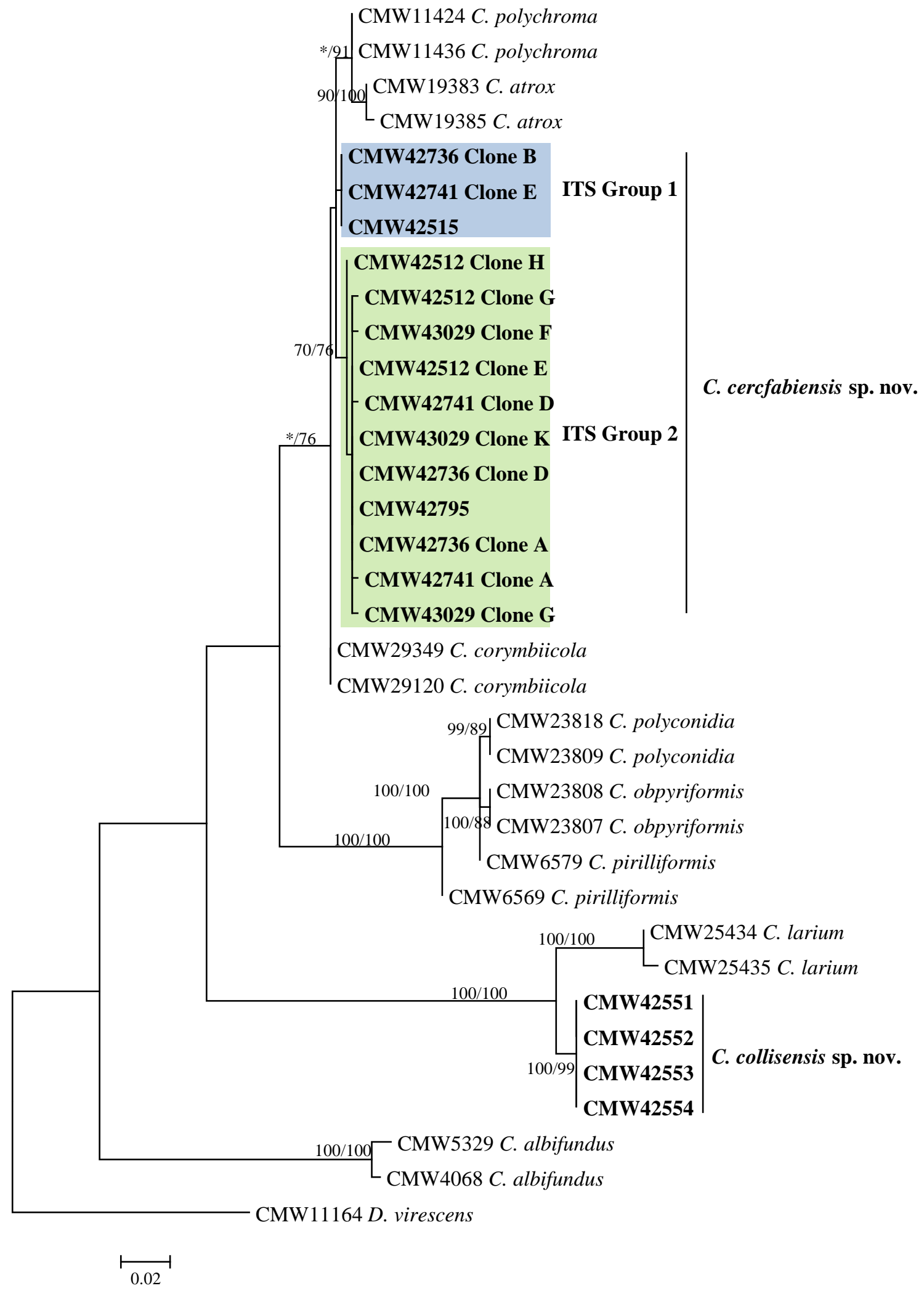

Fig. 3 Phylogenetic tree of the ITS nuclear ribosomal DNA for Ceratocystis species in the Indo-Pacific clade including the new species C. cercfabiensis and C. collisensis. All cloned sequences obtained for C. cercfabiensis representing multiple ITS types (twelve in total) are also included and fall into two groups. Tree based on maximum likelihood (ML) analysis. Isolates in bold were sequenced in this study. Bootstrap values $>70 \%$ for ML and maximum parsimony (MP) are presented above branches as follows: ML/MP, bootstrap values lower than $70 \%$ are marked with *. Davidsoniella virescens (CMW11164) represents the outgroup 


\section{BT1}

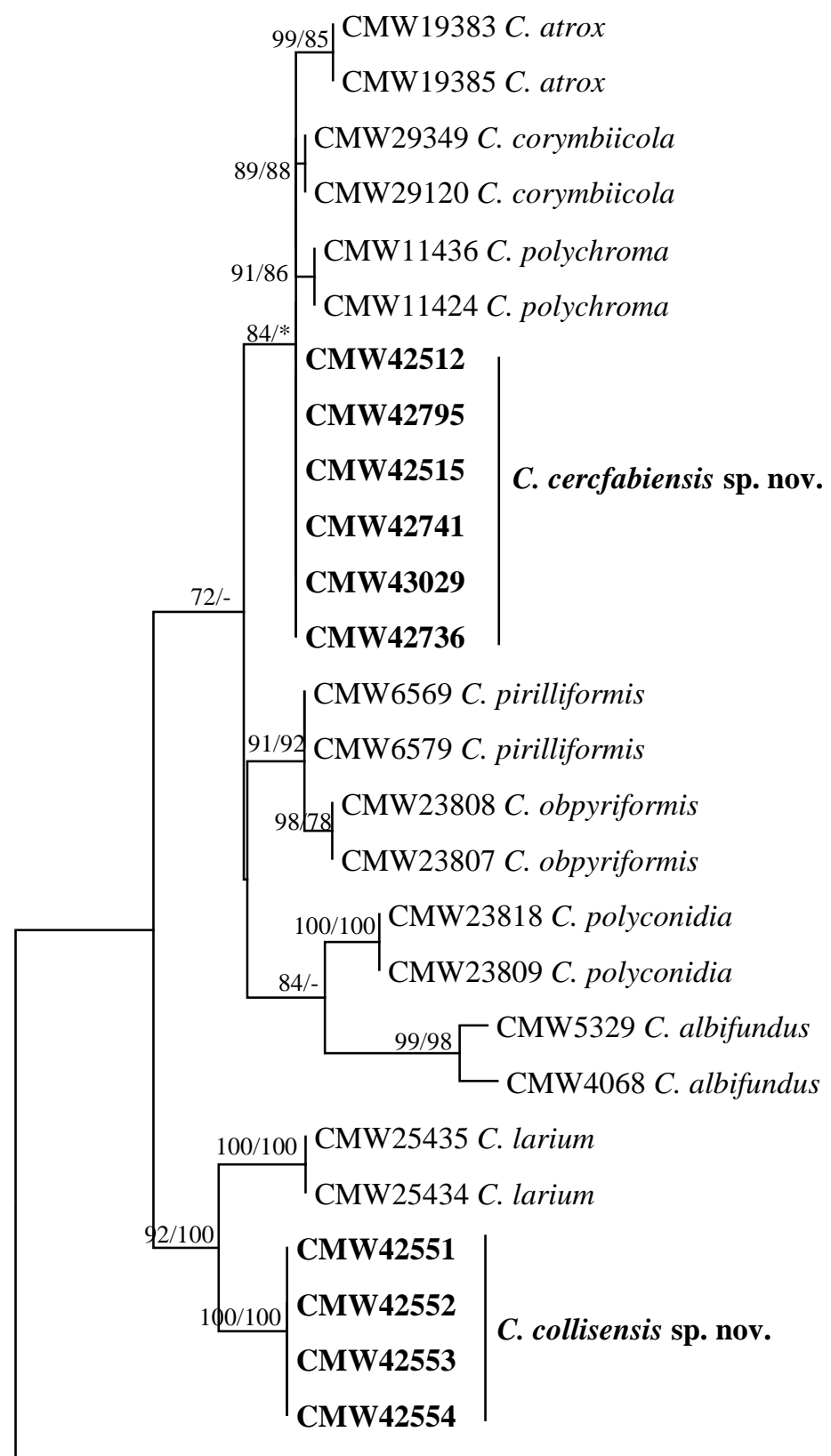

CMW11164 D. virescens

$\underset{0.005}{\stackrel{H}{ }}$

Fig. 4 Phylogenetic tree based on maximum likelihood (ML) analysis of BT1 gene sequences for various Ceratocystis species in the Indo-Pacific clade. Isolates in bold were sequenced in this study. Bootstrap values $>70 \%$ for ML and maximum parsimony (MP) are presented above branches as follows: ML/MP, bootstrap values lower than $70 \%$ are marked with *. Davidsoniella virescens (CMW11164) represents the outgroup 


\section{TEF-1 $\alpha$}

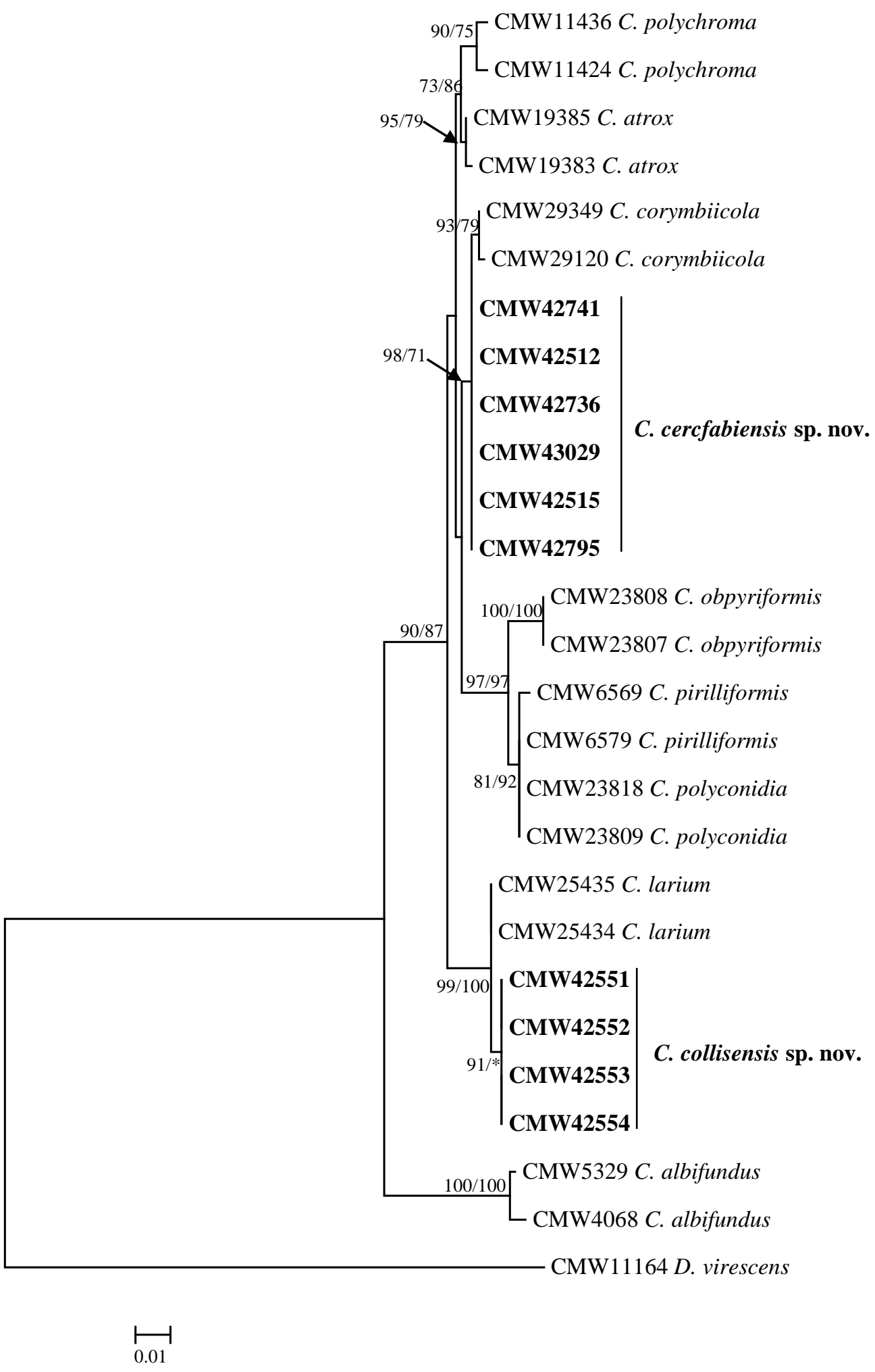

Fig. 5 Phylogenetic tree based on maximum likelihood (ML) analysis of TEF- $1 \alpha$ gene sequences for various Ceratocystis species in the Indo-Pacific clade. Isolates in bold were sequenced in this study. Bootstrap values $>70 \%$ for ML and maximum parsimony (MP) are presented above branches as follows: ML/MP, bootstrap values lower than $70 \%$ are marked with *. Davidsoniella virescens (CMW11164) represents the outgroup 


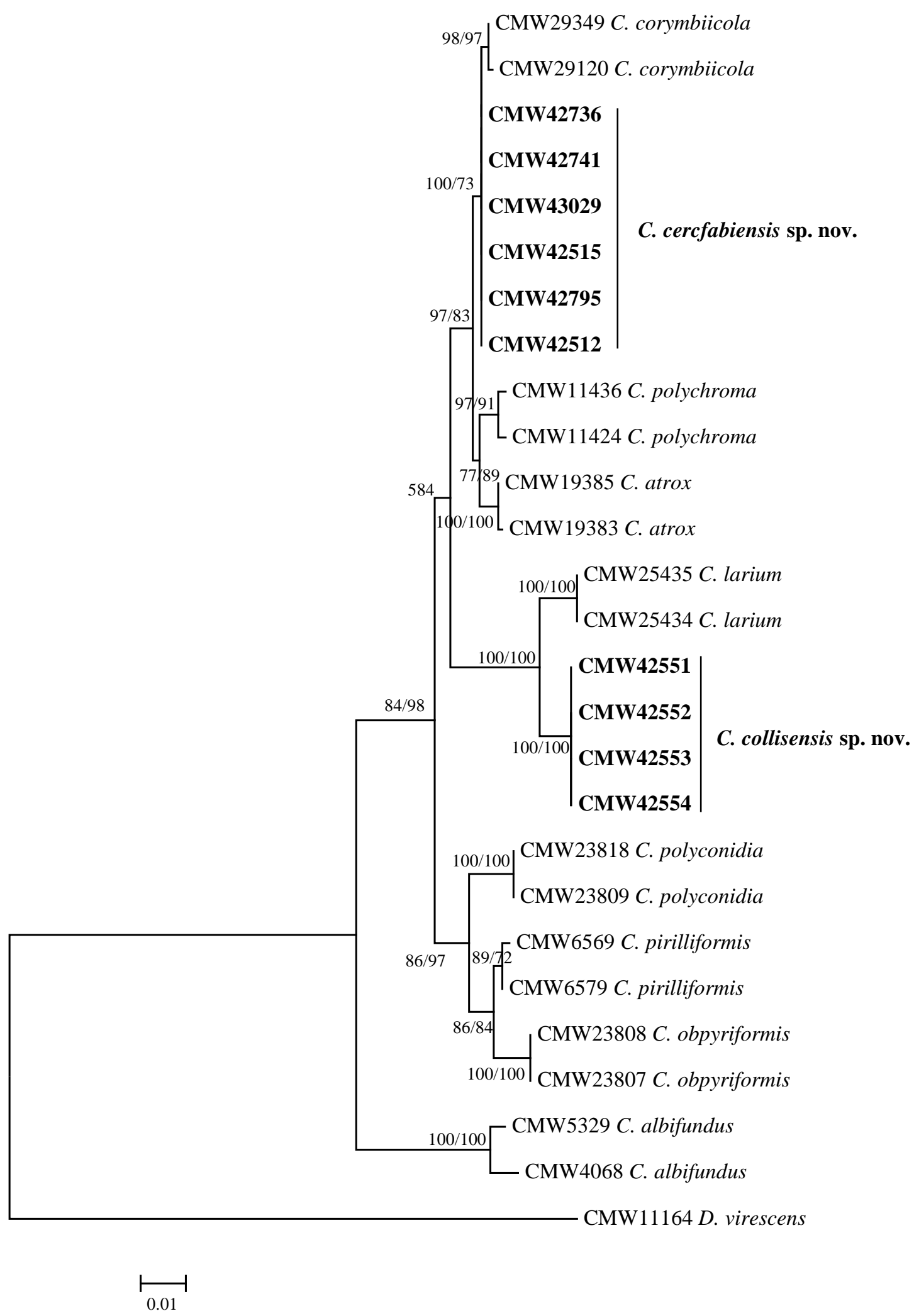

Fig. 6 Phylogenetic tree based on maximum likelihood (ML) analysis of a combined dataset of BT1 and TEF-1 $\alpha$ gene sequences for various Ceratocystis species in the Indo-Pacific clade. Isolates in bold were sequenced in this study. Bootstrap values $>70 \%$ for ML and maximum parsimony (MP) are presented above branches as follows: ML/MP, bootstrap values lower than $70 \%$ are marked with *. Davidsoniella virescens (CMW11164) represents the outgroup 
Phylogenetic analyses of the ITS (Fig. 3), BT1 (Fig. 4), TEF-1 $\alpha$ (Fig. 5) and combined BT1 and TEF-1 $\alpha$ (Fig. 6) gene sequences for both the maximum likelihood (ML) and maximum parsimony (MP) analyses consistently showed that the isolates from China represent two previously unknown species. The position of the fungal species in each phylogenetic clade (species), in relation to each other, differed slightly, but the overall topologies were similar. Isolates obtained from Eucalyptus species in South China were phylogenetically closest to $C$. corymbiicola. It clearly showed that there were two sub-clades of the ITS type for the isolates in this clade (Fig. 3), but both were distinct from previously described Ceratocystis species and more similar to each other than to other species in the genus. Isolates collected from $C$. lanceolata were most closely related to C. larium. Only a single ITS type was found for the eight isolates of this species.

Isolates from Eucalyptus were phylogenetically most similar to C. corymbiicola, C. polychroma and C. atrox in the Indo-Pacific clade (Fig. 3, 4, 5, 6), however, they could be distinguished from these three groups using single nucleotide polymorphism (SNP) analyses for each of the three gene regions sequenced (Table 4, 5). Comparisons of these four groups showed that each group could be separated from the other three by 10-28 unique SNPs for all three gene regions (Table 5). Isolates from Eucalyptus differed from other three species (C. corymbiicola, C. polychroma and C. atrox) by 10, 16, 22 unique SNPs, respectively (Table 4, 5).

\section{Taxonomy}

Based on morphological comparisons and multigene sequence phylogenies, the Ceratocystis isolates from Eucalyptus and C. lanceolata trees in South China represent two undescribed species residing 
Table 4 Summary of polymorphic nucleotides found in the ITS, BT1 and TEF-1 $\alpha$ gene regions generated for the phylogenetic groups of $C$. cercfabiensis, C. corymbiicola, C. atrox and C. polychroma ${ }^{1}$

\begin{tabular}{|c|c|c|c|c|c|c|c|c|c|c|c|c|c|c|c|c|c|c|c|c|c|}
\hline \multirow[t]{2}{*}{ Species } & \multirow{2}{*}{$\begin{array}{l}\text { Isolate } \\
\text { number }\end{array}$} & \multicolumn{20}{|c|}{ ITS } \\
\hline & & 15 & 16 & 37 & 57 & 93 & 108 & 115 & 140 & 179 & 180 & 193 & 377 & 378 & 379 & 380 & 381 & 382 & 383 & 454 & 474 \\
\hline \multirow[t]{14}{*}{ C. cercfabiensis } & CMW42736_Clone A & $\mathrm{C}$ & $\mathrm{C}$ & - & - & $\mathrm{C}$ & - & - & - & - & - & - & - & - & - & - & - & - & - & - & $\mathrm{C}$ \\
\hline & CMW42736_Clone B & $\mathrm{C}$ & $\mathrm{C}$ & - & - & $\mathrm{C}$ & - & - & - & - & - & - & - & - & - & - & - & - & - & - & $\mathrm{C}$ \\
\hline & CMW42736_Clone D & $\mathrm{C}$ & $\mathrm{C}$ & - & - & $\mathrm{C}$ & - & - & - & - & - & - & - & - & - & - & - & - & - & - & $\mathrm{C}$ \\
\hline & CMW42741_Clone A & $\mathrm{C}$ & $\mathrm{C}$ & - & - & $\mathrm{C}$ & - & - & - & - & - & - & - & - & - & - & - & - & - & - & $\mathrm{C}$ \\
\hline & CMW42741_Clone D & $\mathrm{C}$ & $\mathrm{C}$ & - & - & $\mathrm{C}$ & - & - & - & - & - & - & - & - & - & - & - & - & - & - & $\mathrm{C}$ \\
\hline & CMW42741_Clone E & $\mathrm{C}$ & $\mathrm{C}$ & - & - & $\mathrm{C}$ & - & - & - & - & - & - & - & - & - & - & - & - & - & - & $\mathrm{C}$ \\
\hline & CMW42512_Clone E & $\mathrm{C}$ & $\mathrm{C}$ & - & - & $\mathrm{C}$ & - & - & - & - & - & - & - & - & - & - & - & - & - & - & $\mathrm{C}$ \\
\hline & CMW42512_Clone G & $\mathrm{C}$ & $\mathrm{C}$ & - & - & $\mathrm{C}$ & - & - & - & - & - & - & - & - & - & - & - & - & - & - & $\mathrm{C}$ \\
\hline & CMW42512_Clone H & $\mathrm{C}$ & $\mathrm{C}$ & - & - & $\mathrm{C}$ & - & - & - & - & - & - & - & - & - & - & - & - & - & - & $\mathrm{C}$ \\
\hline & CMW43029_Clone F & $\mathrm{C}$ & $\mathrm{C}$ & - & - & $\mathrm{C}$ & - & - & - & - & - & - & - & - & - & - & - & - & - & - & $\mathrm{C}$ \\
\hline & CMW43029_Clone G & $\mathrm{C}$ & $\mathrm{C}$ & - & - & $\mathrm{C}$ & - & - & - & - & - & - & - & - & - & - & - & - & - & - & $\mathrm{C}$ \\
\hline & CMW43029_Clone K & $\mathrm{C}$ & $\mathrm{C}$ & - & - & $\mathrm{C}$ & - & - & - & - & - & - & - & - & - & - & - & - & - & - & $\mathrm{C}$ \\
\hline & CMW42515 & $\mathrm{C}$ & $\mathrm{C}$ & - & - & $\mathrm{C}$ & - & - & - & - & - & - & - & - & - & - & - & - & - & - & $\mathrm{C}$ \\
\hline & CMW42795 & $\mathrm{C}$ & $\mathrm{C}$ & - & - & $\mathrm{C}$ & - & - & - & - & - & - & - & - & - & - & - & - & - & - & $\mathrm{C}$ \\
\hline \multirow[t]{2}{*}{ C. corymbiicola } & CMW29120 & $\mathrm{C}$ & $\mathrm{C}$ & - & G & $\mathrm{T}$ & - & $\mathrm{C}$ & - & - & - & A & - & - & - & - & - & - & $\mathrm{T}$ & $\mathrm{C}$ & $\mathrm{C}$ \\
\hline & CMW29349 & $\mathrm{C}$ & $\mathrm{C}$ & - & G & $\mathrm{T}$ & - & $\mathrm{C}$ & - & - & - & A & - & - & - & - & - & - & $\mathrm{T}$ & $\mathrm{C}$ & $\mathrm{C}$ \\
\hline \multirow[t]{2}{*}{ C. atrox } & CMW19383 & - & $\mathrm{T}$ & - & $\mathrm{G}$ & $\mathrm{C}$ & A & - & - & $\mathrm{G}$ & G & - & $\mathrm{T}$ & $\mathrm{T}$ & $\mathrm{T}$ & $\mathrm{T}$ & $\mathrm{T}$ & $\mathrm{T}$ & $\mathrm{T}$ & - & $\mathrm{N}$ \\
\hline & CMW19385 & - & $\mathrm{T}$ & - & G & $\mathrm{C}$ & A & - & - & G & G & - & $\mathrm{T}$ & $\mathrm{T}$ & $\mathrm{T}$ & $\mathrm{T}$ & $\mathrm{T}$ & $\mathrm{T}$ & $\mathrm{T}$ & - & $\mathrm{N}$ \\
\hline \multirow[t]{2}{*}{ C. polychroma } & CMW11424 & $\mathrm{C}$ & $\mathrm{T}$ & A & G & $\mathrm{C}$ & - & - & $\mathrm{T}$ & - & - & A & - & - & - & - & - & - & - & - & $\mathrm{T}$ \\
\hline & CMW11436 & $\mathrm{C}$ & $\mathrm{T}$ & A & G & $\mathrm{C}$ & - & - & $\mathrm{T}$ & - & - & A & - & - & - & - & - & - & - & - & $\mathrm{T}$ \\
\hline
\end{tabular}




\begin{tabular}{|c|c|c|c|c|c|c|c|c|c|}
\hline \multirow[t]{2}{*}{ Species } & \multirow{2}{*}{$\begin{array}{l}\text { Isolate } \\
\text { number }\end{array}$} & \multicolumn{8}{|c|}{$B T 1$} \\
\hline & & 39 & 163 & 191 & 246 & 251 & 254 & 261 & 485 \\
\hline \multirow[t]{6}{*}{ C. cercfabiensis } & CMW42736 & $\mathrm{T}$ & A & $\mathrm{C}$ & $\mathrm{C}$ & $\mathrm{T}$ & $\mathrm{C}$ & $\mathrm{T}$ & $\mathrm{C}$ \\
\hline & CMW42741 & $\mathrm{T}$ & A & $\mathrm{C}$ & $\mathrm{C}$ & $\mathrm{T}$ & $\mathrm{C}$ & $\mathrm{T}$ & $\mathrm{C}$ \\
\hline & CMW42512 & $\mathrm{T}$ & A & $\mathrm{C}$ & $\mathrm{C}$ & $\mathrm{T}$ & $\mathrm{C}$ & $\mathrm{T}$ & $\mathrm{C}$ \\
\hline & CMW43029 & $\mathrm{T}$ & A & $\mathrm{C}$ & $\mathrm{C}$ & $\mathrm{T}$ & $\mathrm{C}$ & $\mathrm{T}$ & $\mathrm{C}$ \\
\hline & CMW42515 & $\mathrm{T}$ & A & $\mathrm{C}$ & $\mathrm{C}$ & $\mathrm{T}$ & $\mathrm{C}$ & $\mathrm{T}$ & $\mathrm{C}$ \\
\hline & CMW42795 & $\mathrm{T}$ & A & $\mathrm{C}$ & $\mathrm{C}$ & $\mathrm{T}$ & $\mathrm{C}$ & $\mathrm{T}$ & $\mathrm{C}$ \\
\hline \multirow[t]{2}{*}{ C. corymbiicola } & CMW29120 & $\mathrm{T}$ & A & $\mathrm{C}$ & $\mathrm{C}$ & G & - & $\mathrm{T}$ & $\mathrm{C}$ \\
\hline & CMW29349 & $\mathrm{T}$ & A & $\mathrm{C}$ & $\mathrm{C}$ & G & - & $\mathrm{T}$ & $\mathrm{C}$ \\
\hline \multirow[t]{2}{*}{ C. atrox } & CMW19383 & $\mathrm{C}$ & $\mathrm{G}$ & $\mathrm{T}$ & $\mathrm{C}$ & $\mathrm{T}$ & $\mathrm{C}$ & $\mathrm{T}$ & $\mathrm{T}$ \\
\hline & CMW19385 & $\mathrm{C}$ & G & $\mathrm{T}$ & $\mathrm{C}$ & $\mathrm{T}$ & $\mathrm{C}$ & $\mathrm{T}$ & $\mathrm{T}$ \\
\hline \multirow[t]{2}{*}{ C. polychroma } & CMW11424 & $\mathrm{T}$ & A & $\mathrm{C}$ & $\mathrm{T}$ & $\mathrm{T}$ & $\mathrm{C}$ & $\mathrm{C}$ & $\mathrm{C}$ \\
\hline & CMW11436 & $\mathrm{T}$ & A & $\mathrm{C}$ & $\mathrm{T}$ & $\mathrm{T}$ & $\mathrm{C}$ & $\mathrm{C}$ & $\mathrm{C}$ \\
\hline
\end{tabular}

\begin{tabular}{|c|c|c|c|c|c|c|c|c|c|c|c|c|}
\hline \multirow[t]{2}{*}{ Species } & \multirow{2}{*}{$\begin{array}{l}\text { Isolate } \\
\text { number }\end{array}$} & \multicolumn{11}{|c|}{$T E F$} \\
\hline & & 14 & 135 & 136 & 137 & 325 & 361 & 362 & 508 & 636 & 646 & 670 \\
\hline \multirow[t]{6}{*}{ C. cercfabiensis } & CMW42736 & $\mathrm{T}$ & - & - & $\mathrm{T}$ & $\mathrm{G}$ & $\mathrm{C}$ & $\mathrm{C}$ & $\mathrm{G}$ & $\mathrm{A}$ & $\mathrm{T}$ & $\mathrm{C}$ \\
\hline & CMW42741 & $\mathrm{T}$ & - & - & $\mathrm{T}$ & G & $\mathrm{C}$ & $\mathrm{C}$ & $\mathrm{G}$ & A & $\mathrm{T}$ & $\mathrm{C}$ \\
\hline & CMW42512 & $\mathrm{T}$ & - & - & $\mathrm{T}$ & G & $\mathrm{C}$ & $\mathrm{C}$ & $\mathrm{G}$ & $\mathrm{A}$ & $\mathrm{T}$ & $\mathrm{C}$ \\
\hline & CMW43029 & $\mathrm{T}$ & - & - & $\mathrm{T}$ & G & $\mathrm{C}$ & $\mathrm{C}$ & $\mathrm{G}$ & A & $\mathrm{T}$ & $\mathrm{C}$ \\
\hline & CMW42515 & $\mathrm{T}$ & - & - & $\mathrm{T}$ & G & $\mathrm{C}$ & $\mathrm{C}$ & G & A & $\mathrm{T}$ & $\mathrm{C}$ \\
\hline & CMW42795 & $\mathrm{T}$ & - & - & $\mathrm{T}$ & G & $\mathrm{C}$ & $\mathrm{C}$ & G & $\mathrm{A}$ & $\mathrm{T}$ & $\mathrm{C}$ \\
\hline \multirow[t]{2}{*}{ C. corymbiicola } & CMW29120 & $\mathrm{T}$ & - & - & - & G & $\mathrm{C}$ & A & G & A & $\mathrm{T}$ & $\mathrm{C}$ \\
\hline & CMW29349 & $\mathrm{T}$ & - & - & - & G & $\mathrm{C}$ & A & $\mathrm{G}$ & A & $\mathrm{T}$ & $\mathrm{C}$ \\
\hline \multirow[t]{2}{*}{ C. atrox } & CMW19383 & $\mathrm{T}$ & - & $\mathrm{T}$ & $\mathrm{T}$ & G & $\mathrm{C}$ & $\mathrm{C}$ & A & $\mathrm{T}$ & $\mathrm{C}$ & $\mathrm{T}$ \\
\hline & CMW19385 & $\mathrm{T}$ & - & $\mathrm{T}$ & $\mathrm{T}$ & G & $\mathrm{C}$ & $\mathrm{C}$ & A & $\mathrm{T}$ & $\mathrm{C}$ & $\mathrm{T}$ \\
\hline \multirow[t]{2}{*}{ C. polychroma } & CMW11424 & $\mathrm{C}$ & $\mathrm{T}$ & $\mathrm{T}$ & $\mathrm{T}$ & A & $\mathrm{T}$ & $\mathrm{C}$ & $\mathrm{G}$ & $\mathrm{T}$ & $\mathrm{C}$ & $\mathrm{T}$ \\
\hline & CMW11436 & $\mathrm{C}$ & $\mathrm{T}$ & $\mathrm{T}$ & $\mathrm{T}$ & $\mathrm{A}$ & $\mathrm{T}$ & $\mathrm{C}$ & $\mathrm{G}$ & $\mathrm{T}$ & $\mathrm{C}$ & $\mathrm{T}$ \\
\hline
\end{tabular}

${ }^{1}$ Only polymorphic nucleotides occurring in all of the isolates are shown. Fixed polymorphisms for each group (or fixed but shared between two groups) are highlighted 
Table 5 Number of unique alleles found in Ceratocystis cercfabiensis, C. corymbiicola, C. atrox and C. polychroma ${ }^{1}$

\begin{tabular}{llll}
\hline ITS/BT1/TEF-1 $\alpha$ & C. corymbiicola & C. atrox & C. polychroma \\
\hline C. cercfabiensis & $10(6 / 2 / 2)$ & $22(13 / 4 / 5)$ & $16(6 / 2 / 8)$ \\
C. corymbiicola & & $28(15 / 6 / 7)$ & $22(8 / 4 / 10)$ \\
C. $a t r o x$ & & $25(14 / 6 / 5)$ \\
\hline
\end{tabular}

${ }^{1}$ The order of the three genes: Total numbers (ITS/BT1/TEF-1 $\alpha$ ) 


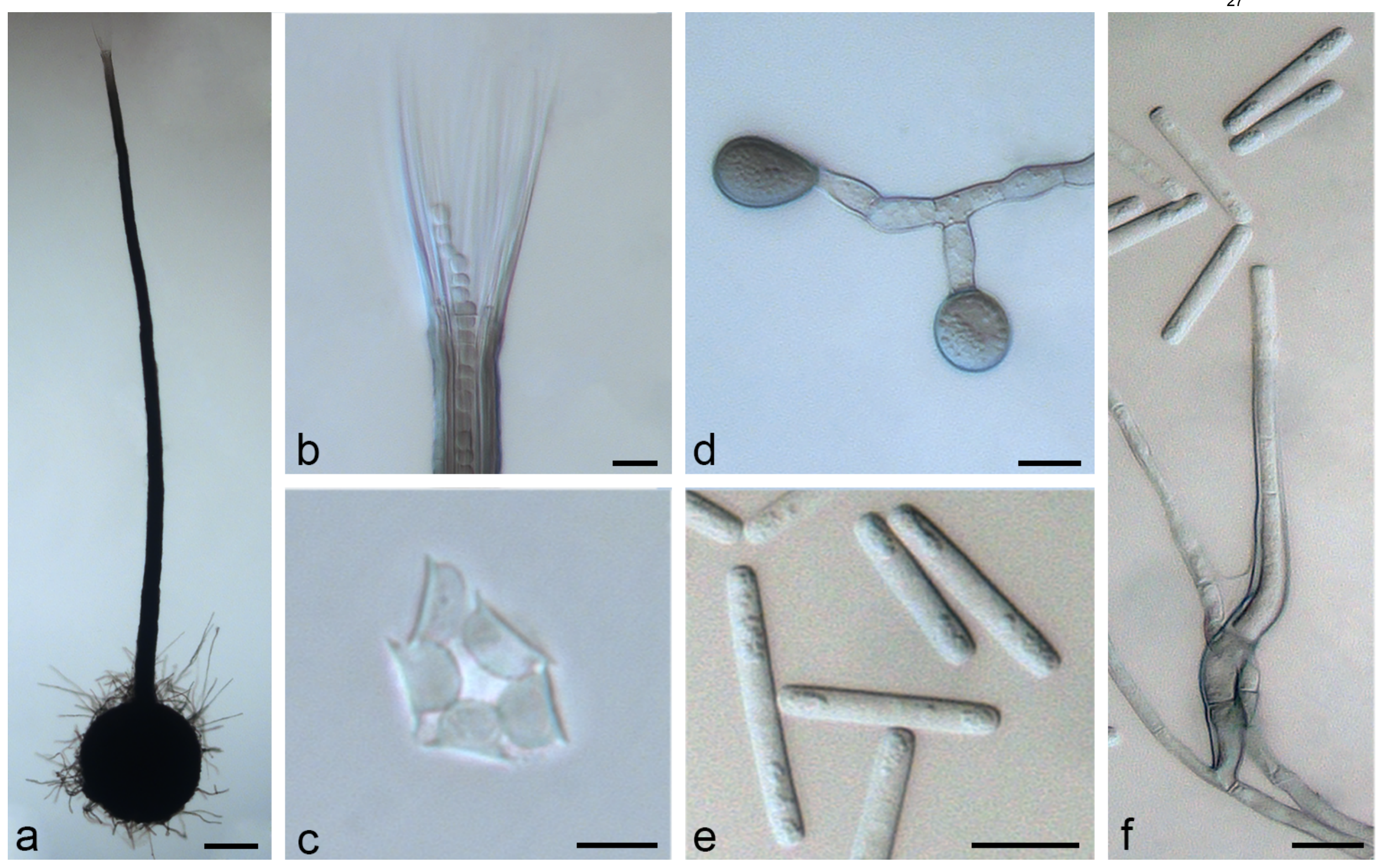

Fig. 7 Morphological characteristics of Ceratocystis cercfabiensis. a. Globose ascomata. b. Divergent ostiolar hyphae. c. Hat-shaped ascospores. d. Thick-walled chlamydospores. e. Bacilliform conidia. f. Flask-shaped conidiophores. Scale Bars: $\mathrm{a}=100 \mu \mathrm{m}, \mathrm{c}=5 \mu \mathrm{m}, \mathrm{b}, \mathrm{d}, \mathrm{e}, \mathrm{f}=10 \mu \mathrm{m}$ 
in the Indo-Pacific Clade, clearly separated from other Ceratocystis species. These novel species are described as follows:

Ceratocystis cercfabiensis F.F. Liu, Jol. Roux \& S.F. Chen sp. nov. (Fig. 7)

MycoBank No. MB811888

Etymology the name "cercfabiensis" refers to the CERC-FABI Tree Protection Programme (CFTPP) that represents a co-operative research venture established between the China Eucalypt Research Centre (CERC), an Institute of the Chinese Academy of Forestry and the Forestry and Agricultural Biotechnology Institute (FABI) at the University of Pretoria, South Africa (http://www.fabinet.up.ac.za).

Culture characteristics Colonies on MEA greenish olivaceous (23"'), reverse greenish olivaceous (23"'). Mycelium immersed and superficial. Hyphae smooth, septate, without constriction at septa. Colony surfaces scattered with black ascomata. Optimal temperature for growth $25^{\circ} \mathrm{C}$, covering the $90 \mathrm{~mm}$ plates after 14 days, no growth at $5^{\circ} \mathrm{C}$ or $35^{\circ} \mathrm{C}$. After 14 days, colonies at $10^{\circ} \mathrm{C}, 15^{\circ} \mathrm{C}, 20^{\circ} \mathrm{C}$, $25^{\circ} \mathrm{C}$ and $30^{\circ} \mathrm{C}$ reached $7 \mathrm{~mm}, 29 \mathrm{~mm}, 50 \mathrm{~mm}, 73 \mathrm{~mm}$ and $57 \mathrm{~mm}$, respectively.

Sexual state Ascomata scattered, with bulbous bases and long necks formed superficially or partially submerged in the substrate. Ascomatal bases dark brown to black, globose, (100-) 137 $218.8(-302) \mu \mathrm{m}$ long and (79-) $138-231(-286) \mu \mathrm{m}$ wide in diameter. Spines or ornamentations absent. Ascomatal necks brown to black, erect, slender, (473-) 829 - 1400 (-1756) $\mu \mathrm{m}$ long, (14-) 17 - 26 (-33) $\mu \mathrm{m}$ wide at apices, (22-) 30 - 43 (-55) $\mu \mathrm{m}$ wide at bases. Ostiolar hyphae present, hyaline, divergent, (32-) 48 - 70 (-82) $\mu \mathrm{m}$ long. Asci not observed. Ascospores hat-shaped, invested in sheaths, aseptate, (4.1-) $5.7-6.8$ (-7.5) $\mu \mathrm{m}$ long and (2.5-) $3.1-3.9$ (-4.6) $\mu \mathrm{m}$ wide with sheaths in 
side view. Ascospores accumulating in buff yellow (19 d) mucilaginous masses at the apices of ascomatal necks.

Asexual state producing phialides, typical of Thielaviopsis with enteroblastic conidium ontogeny. Conidiophores of only one type, flask-shaped, hyaline at apices, becoming brown towards bases, multi-septate, phialidic, tubular, tapering at apices (42-) $60-145$ (-291) $\mu \mathrm{m}$ long, (2.7-) $3.9-5.5$ (-7.4) $\mu \mathrm{m}$ wide at apices and (3.2-) $4-6(-7.7) \mu \mathrm{m}$ wide at bases. Conidia hyaline, aseptate, bacilliform to dumbbell shaped, (8.8-) 16.2 - 25.6 (-49.9) $\mu \mathrm{m}$ long and (2.7-) $3.4-4.6(-2.7) \mu \mathrm{m}$ wide. Chlamydospores ovoid, smooth, formed singly, terminal, hyaline when young, becoming dark brown when mature, (9.9-) 12.1 - $15.0(-16.7) \times(7.0-) 9.2-11.5(-13.0) \mu \mathrm{m}$ in size.

Habitat stumps of recently felled (less than one month) Eucalyptus trees in China.

Known distribution GuangDong, GuangXi, FuJian and HaiNan Provinces, China.

Specimens examined China, HaiNan Province, LinGao County, Eucalyptus plantation. Isolated from recently harvested tree stumps, September 2013, S.F. Chen, F.F. Liu \& T. Huang, HOLOTYPE PREM 61229, culture ex-type CMW43029 = CERC2170 = CBS 139654.

Additional specimens China, GuangXi Province, YuLin Region, BoBai County, Eucalyptus plantation. Isolated from recently harvested tree stumps, October 2013, S.F. Chen, F.F. Liu \& G.Q. Li, PARATYPE PREM 61230, culture ex-type CMW42515 = CERC2345 = CBS 139655; China, GuangDong Province, JiangMen Region, XinHui Distict, Eucalyptus plantation. Isolated from recently harvested tree stumps, January 2014, S.F. Chen, F.F. Liu \& G.Q. Li, PARATYPE PREM 61231, culture ex-type CMW42795 = CERC2687 = CBS 139656. 
Table 6 Morphological comparisons of C. cercfabiensis and other phylogenetically closely related species ${ }^{1}$

\begin{tabular}{|c|c|c|c|c|}
\hline & C. cercfabiensis & C. corymbiicola & C. polychroma & C. atrox \\
\hline Ascomata base & $(100-) 137-218.8(-302) \times(79-) 138-231(-286)^{2}$ & $(159-) 189-241(-290) \times(160.5-) 185.0-237.5(-272.5)$ & (208-) $217-261$ (-269) diam & (120-) $140-180(-222)$ diam \\
\hline Ascomata base Average & $177.9 \times 184.5^{3}$ & $215.0 \times 211.0$ & $239.0 \times 239.0$ & $160.0 \times 160.0$ \\
\hline Ascomata neck & $(473-) 829-1400(-1756)$ & $(603.0-) 755.0-1009.0(-1097.5)$ & (837-) $849-1071(-1187)$ & (277-) $313-401(-451)$ \\
\hline Ascomata neck Average & 1114.5 & 882.0 & 960.0 & 357.0 \\
\hline Ascospores & $(4.1-) 5.7-6.8(-7.5) \times(2.5-) 3.1-3.9(-4.6)$ & $(4.5-) 5.0-5.5(-6.0) \times(2.5-) 3.0-3.5(-4.0)$ & $5-7 \times 3-4$ & $4-6 \times 3-4$ \\
\hline Ascospores Average & $6.3 \times 3.5$ & $5.3 \times 3.3$ & $6.0 \times 3.5$ & $5.0 \times 3.5$ \\
\hline Bacilliform conidia & $(8.8-) 16.2-25.6(-49.9) \times(2.7-) 3.4-4.6(-2.7)$ & $(11.0-) 15.0-21.5(-27.5) \times(3.0-) 3.5-4.5(-5.5)$ & $(13-) 16-24(-26) \times 3-5$ & (9-) $11-15(-17) \times 3-5$ \\
\hline Bacilliform conidia Average & $20.9 \times 4.0$ & $18.3 \times 4.0$ & $20.0 \times 4.0$ & $13.0 \times 4.0$ \\
\hline Barrel-shaped conidia & not present & $(7.5-) 8.5-12.0(-14.5) \times(3.5-) 4.0-5.5(-6.5)$ & $9-11 \times 6-8$ & $\begin{array}{l}\text { (7-) } 8-12(-14) \times(5-) 6-8(- \\
9)\end{array}$ \\
\hline Barrel-shaped conidia Average & & $10.3 \times 4.8$ & $10.0 \times 7.0$ & $10.0 \times 7.0$ \\
\hline Chlamydospore & $(9.9-) 12.1-15.0(-16.7) \times(7.0-) 9.2-11.5(-13.0)$ & $(8.5-) 11.0-12.0(-16.5) \times(6.5-) 8.0-11.0(-16.5)$ & $11-14 \times 8-14$ & not present \\
\hline Chlamydospore Average & $13.6 \times 10.4$ & $11.5 \times 9.5$ & $12.5 \times 11.0$ & \\
\hline
\end{tabular}

${ }^{1}$ All measurements are in $\mu \mathrm{m}$

${ }^{2}$ Measurements are presented in the format [(minimum-) (average - standard deviation $)-($ average + standard deviation) $(-$ maximum $)$ ]

${ }^{3}$ Measurements are presented in the format minimum $\times$ maximum 
Notes Ceratocystis cercfabiensis is phylogenetically most closely related to C. corymbiicola (Nkuekam et al. 2012), C. polychroma (Van Wyk et al. 2004) and C. atrox (Van Wyk et al. 2007b). It can be distinguished from these species by the size of their ascomatal bases, necks and ascospores (Table 6). When grown on $2 \%$ MEA, the ascomatal bases of $C$. cercfabiensis (average $178 \times 184 \mu \mathrm{m}$ ) are smaller than those of $C$. corymbiicola (average $215 \times 211 \mu \mathrm{m}$ ) and $C$. polychroma (average $239 \times 239 \mu \mathrm{m}$ ), but larger than those of $C$. atrox (average $160 \times 160 \mu \mathrm{m}$ ). Ascomatal necks of $C$. cercfabiensis (average $1115 \mu \mathrm{m}$ ) are much longer than those of $C$. corymbiicola (average $882 \mu \mathrm{m}$ ), $C$. polychroma (average $960 \mu \mathrm{m}$ ) and C. atrox (average $357 \mu \mathrm{m}$ ). Ascospores of C. cercfabiensis (average $6.3 \times 3.5 \mu \mathrm{m}$ ) are also larger than those of $C$. corymbiicola (average $5.3 \times 3.3 \mu \mathrm{m}$ ), $C$. polychroma (average $6.0 \times 3.5 \mu \mathrm{m})$ and $C$. atrox (average $5 \times 3.5 \mu \mathrm{m}$ ).

Ceratocystis collisensis F.F. Liu, M.J. Wingf. \& S.F. Chen sp. nov. (Fig. 8) MycoBank No. MB811889

Etymology the name "collis" is derived from that Latin word "mountain", reflecting the fact that the samples were collected from the WuYi Mountains in China.

Culture characteristics Colonies on MEA olivaceous (21'’k), reverse olivaceous (21'’k). Mycelium immersed and superficial, with white-grey mycelia at the edge. Hyphae smooth, septate, without constriction at septa. Colony surfaces with scattered black ascomata. Optimal temperature for growth $25^{\circ} \mathrm{C}$, slow growing, no growth at $5^{\circ} \mathrm{C}$ or $35^{\circ} \mathrm{C}$. After 14 days, colonies at $10^{\circ} \mathrm{C}, 15^{\circ} \mathrm{C}$, $20^{\circ} \mathrm{C}, 25^{\circ} \mathrm{C}$ and $30^{\circ} \mathrm{C}$ reached $10 \mathrm{~mm}, 30 \mathrm{~mm}, 42 \mathrm{~mm}, 50 \mathrm{~mm}$ and $41 \mathrm{~mm}$, respectively. 

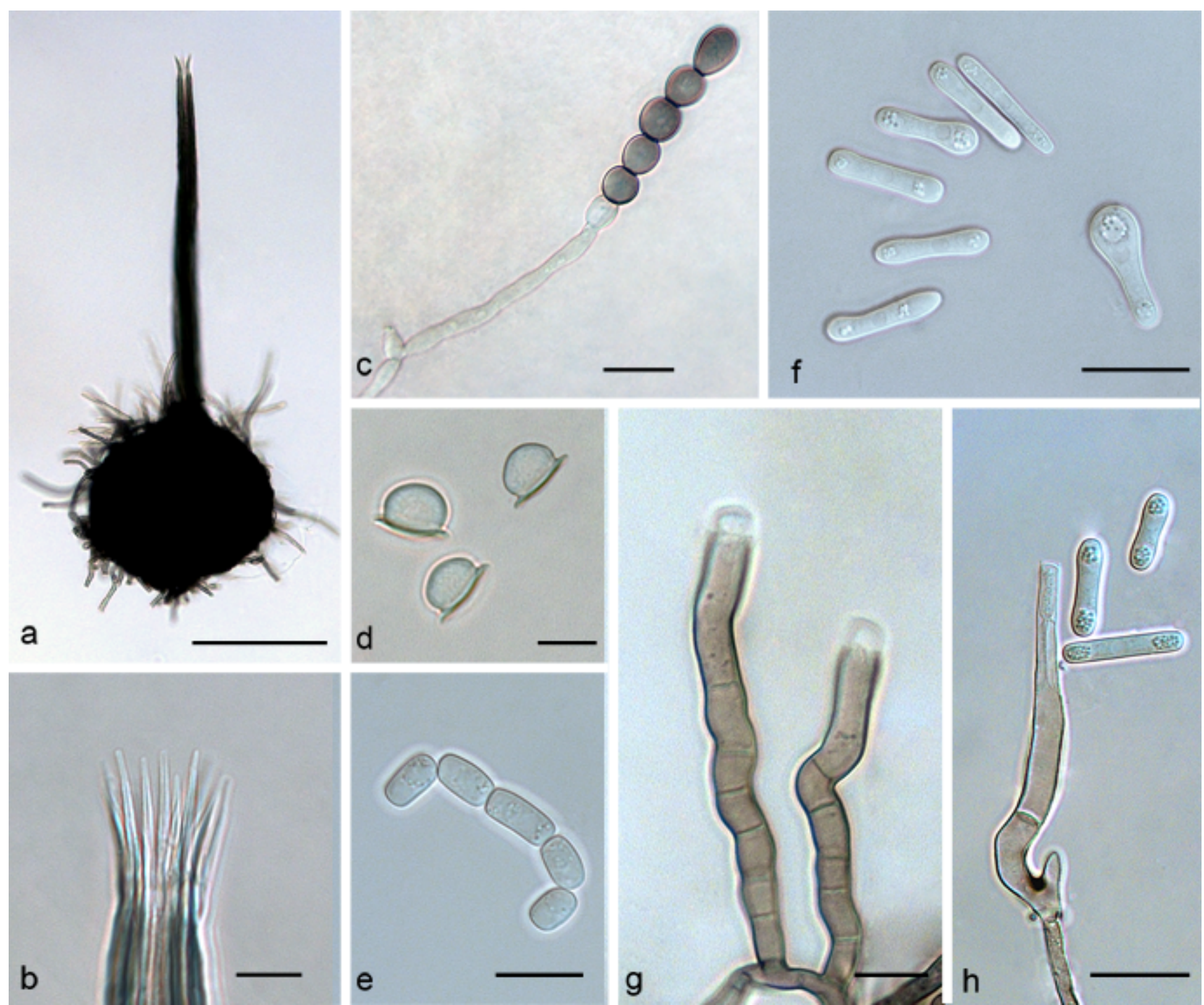

Fig. 8 Morphological characteristics of Ceratocystis collisensis. a. Ascomata with globose to obpyriform bases. b. Divergent ostiolar hyphae. c. Chain of aleurioconidia. d. Hat-shaped ascospores in side view. e. Barrel-shaped conidia in a chain. f. Various shapes of bacilliform conidia. g. Broader conidiophores with emerging barrel-shaped conidia. $\mathrm{h}$. Flask-shaped conidiophores. Scale Bars: $\mathrm{a}=100 \mu \mathrm{m}, \mathrm{b}, \mathrm{c}, \mathrm{e}, \mathrm{f}, \mathrm{g}, \mathrm{h}=10 \mu \mathrm{m}, \mathrm{d}=5 \mu \mathrm{m}$ 
Sexual state Ascomatal bases black, globose to obpyriform, (152-) $174-253$ (-304) $\mu \mathrm{m}$ long and (134-) 164 - 224 (-255) $\mu \mathrm{m}$ wide in diameter. Spines or ornamentations absent. Ascomatal necks dark brown to black, erect, slender, (208-) $301-423$ (-527) $\mu \mathrm{m}$ long, (12-) 15 - 20 (-25) $\mu \mathrm{m}$ wide at apices and (18-) 25 - 33 (-39) $\mu \mathrm{m}$ wide at bases. Ostiolar hyphae present, hyaline, divergent, (6-) 16 - 26 (-31) $\mu \mathrm{m}$ long. Asci not observed. Ascospores hat-shaped, invested in sheaths, aseptate, (5.6-) $6.5-7.8(-8.4) \mu \mathrm{m}$ long and (2.7-) $3.6-4.6(-5.3) \mu \mathrm{m}$ wide with sheaths in side view. Ascospores accumulating in buff yellow (19 d) mucilaginous masses at the apices of ascomatal necks.

Asexual state phialidic, typical of Thielaviopsis with enteroblastic conidium ontogeny. Conidiophores of two types, flask shaped producing bacilliform conidia, hyaline at apices, turning brown towards bases, multi-septate, lageniform, tubular, variable in size when terminal on hyphae, tapering at apices, (46-) 47 - 337 (-129) $\mu \mathrm{m}$ long, (2.3-) 3.6 - 4.9 (-6.2) $\mu \mathrm{m}$ wide at apices and (2.3-) $4.2-6.2(-7.7) \mu \mathrm{m}$ wide at bases or untapered and broader producing barrel-shaped conidia, borne near the bases of ascomata, light brown, flaring, (15-) $34-79$ (-121) $\mu \mathrm{m}$ long, (3.3-) $4.5-7$ (-9) $\mu \mathrm{m}$ wide at apices and (2.8-) 3.8 - 5 (-6.4) $\mu \mathrm{m}$ wide at bases. Bacilliform conidia hyaline, aseptate, cylindrical to dumbbell-shaped, (10.7-) 14.5 - $21.3(-32.3) \mu \mathrm{m}$ long and (2.9-) $3.4-4.4(-5.6) \mu \mathrm{m}$ wide. Barrel-shaped conidia hyaline, aseptate, in chains, (5.4-) $6.1-8.7(-10.9) \mu \mathrm{m}$ long and (3.7-) $4.4-6.3(-7.9) \mu \mathrm{m}$ wide. Aleurioconidia ovoid, smooth, dark brown, embedded in agar, produced in chains, (9.2-) $11.3-14.4(-17.6) \times(7.2-) 8.8-11.1(-13.7) \mu \mathrm{m}$ in size.

Habitat stumps of recently felled (less than one month) Cunninghamia lanceolata trees in China. 
Known distribution FuJian Province, China.

Specimen examined China, FuJian Province, ZhangZhou Region, ChangTai County, Cunninghamia lanceolata plantation. Isolated from recently harvested tree stumps, October 2013, S.F. Chen, F.F. Liu \& G.Q. Li, HOLOTYPE PREM 61232, culture ex-type CMW42552 = CERC2459 = CBS 139679.

Additional specimens China, FuJian Province, NanPing Region. JianOu County, Cunninghamia lanceolata plantation. Isolated from recently harvested tree stumps, November 2013, S.F. Chen, F.F. Liu \& G.Q. Li, PARATYPE PREM 61233, culture ex-type CMW42553 = CERC2465 = CBS 139646; China, FuJian Province, NanPing Region. JianOu County, Cunninghamia lanceolata plantation. Isolated from recently harvested tree stumps, November 2013, S.F. Chen, F.F. Liu \& G.Q. Li, PARATYPE PREM 61234, culture ex-type CMW42554 = CERC2466 = CBS 139647.

Notes Ceratocystis collisensis is phylogenetically most closely related to C. larium. It can be distinguished from this species by the size of its ascomatal bases, necks, ascospores and aleurioconidia. Ascomatal bases of $C$. collisensis (average $214 \times 194 \mu \mathrm{m}$ ) are larger than those of $C$. larium (average $152 \times 170 \mu \mathrm{m}$ ), but ascomatal necks (average $362 \mu \mathrm{m}$ ) are shorter than those of $C$. larium (average $460 \mu \mathrm{m}$ ). Ascospores of $C$. collisensis (average $7.2 \times 4.1 \mu \mathrm{m}$ ) are longer and wider than those of $C$. larium (average $5.5 \times 3.0 \mu \mathrm{m}$ ). Aleurioconidia of $C$. collisensis (average $12.9 \times 10.0$ $\mu \mathrm{m}$ ) are larger than those of $C$. larium (average $11 \times 9 \mu \mathrm{m}$ ) (Van Wyk et al. 2009). 


\section{Discussion}

This study provides descriptions for two previously unknown Ceratocystis species, C. cercfabiensis and $C$. collisensis, from China. It also represents the first record of Ceratocystis species from China that reside in the Indo-Pacific biogeographic group of this genus (Mbenoun et al. 2014). There are only six previous reports of Ceratocystis species from China and all species reside in the South American Clade. These species include C. manginecans from recently harvested stumps of Eucalyptus in GuangDong Province (Chen et al. 2013; Fourie et al. 2015), and C. fimbriata s.l, causing a disease on Eucalyptus (Li et al. 2014b), Ipomoea batatas (sweet potato; Sy 1956), Punica granatum (pomegranate; Huang et al. 2003; Xu et al. 2011), Colocasia esculenta (taro; Huang et al. 2008) and Eriobotrya japonica (loquat; Li et al. 2014a). Considering the number of Ceratocystis species found in other countries, and the small number of studies on species of Ceratocystis and other Ceratocystidaceae found in China, the discovery of $C$. cercfabiensis and $C$. collisensis suggests that many other species in the genus and family remain to be discovered in this geographic area.

Ceratocystis cercfabiensis was found at all Eucalyptus sites sampled and in four Provinces of China. This suggests that it has a wide geographic distribution in the region. In contrast, $C$. collisensis was obtained only from C. lanceolata, at two sites in the FuJian Province. This is the first report of a Ceratocystis species from a Cunninghamia sp. A very limited number of C. lanceolata trees were sampled in this study and surveys of $C$. lanceolata and related species in China should yield additional isolates of this fungus and make it possible to gain knowledge of its relative importance, especially given that this is the first Ceratocystis sp. to be found on a conifer subsequent to the taxonomic revision of de Beer et al. (2014). All previous reports of Ceratocystis species from conifers represent species of Huntiella and Endoconidiophora (De Beer et al. 2014). 
Ceratocystis cercfabiensis is phylogenetically most closely related to C. corymbiicola (Nkuekam et al. 2012), C. polychroma (Van Wyk et al. 2004) and C. atrox (Van Wyk et al. 2007b). All three of these species have been reported from Syzygium and Eucalyptus (Myrtaceae). Ceratocystis corymbiicola and C. atrox were reported from Eucalyptus trees in Australia (Nkuekam et al. 2012; Van Wyk et al. 2007b) and C. polychroma from dying S. aromaticum (clove) trees in Indonesia (Van Wyk et al. 2004). However, comparisons of sequence data showed that C. cercfabiensis isolates represent a distinct clade in this group. This new species could also be distinguished from these three Ceratocystis species based on the fact that it has distinctly longer ascomatal necks, larger ascospores and that dark barrel-shaped aleurioconidia found in some species of Ceratocystis appear not to be present.

Ceratocystis collisensis is most closely related to C. larium. The latter species was described from Styrax benzoin trees being tapped for their aromatic resin in Indonesia (Van Wyk et al. 2009). These two species form a distinct sub-clade in the Indo-Pacific Clade that has been recognised in Ceratocystis (De Beer et al. 2014; Mbenoun et al. 2014), but they are distinct from each other based on sequence data as well as morphology.

The delimitation of species in Ceratocystis has been strongly reliant on sequence data from the ITS region, which has also been identified as the universal barcoding region for fungi (Schoch et al. 2012). However, in this study, we used cloning to provide direct evidence for the occurrence of multiple ITS types in $C$. cercfabiensis. Our results revealed that more than one ITS haplotype can occur in a single isolate, which has also been reported previously for Ceratocystis species in the South American Clade (Naidoo et al. 2013; Harrington et al. 2014; Fourie et al. 2015). The ITS region should, thus, be used with caution for species delineation in Ceratocystis. Although multiple ITS types were found in $C$. cercfabiensis, both groups represented clades distinct from other 
Ceratocystis species, thus supporting our BT1 and TEF-1 $\alpha$ data showing that $C$. cercfabiensis represents a novel species.

Neither $C$. cercfabiensis nor $C$. collisensis were associated with disease or death of trees, but were obtained from fresh harvesting wounds. The recent description of a disease of Eucalyptus in China, caused by C. fimbriata s.l. (Li et al. 2014b), and reports of disease and death of Eucalyptus species caused by species of Ceratocystis in Africa (Roux et al. 1999, 2000, 2004) and South America (Barnes et al. 2003; Rodas et al. 2008; Van Wyk et al. 2012), however, suggest that these fungi could become important to Eucalyptus forestry in China. They clearly deserve further study in the future.

Acknowledgements This study was initiated through the bilateral agreement between the Governments South Africa and China, and we are grateful for the funding via projects 2012DFG31830 (International Science \& Technology Cooperation Program of China), 31400546 (National Natural Science Foundation of China: NSFC), 2010KJCX015-03 (Forestry Science and Technology Innovation Project of Guangdong Province of China). We acknowledge members of Tree Protection and Cooperation Programme (TPCP) and the National Research Foundation (NRF), South Africa for financial support. Tao Huang is thanked for assistance with the fieldwork, and Arista Fourie for the help with the cloning of isolates.

\section{References}

Al Adawi AO, Barnes I, Khan IA, Al Subhi AM, Al Jahwari AA, Deadman ML, Wingfield BD, Wingfield MJ (2013) Ceratocystis manginecans associated with a serious wilt disease of two native legume trees in Oman and Pakistan. Australas Plant Pathol 42:179-193

Barnes I, Roux J, Wingfield BD, Neill MO, Wingfield MJ (2003) Ceratocystis fimbriata infecting Eucalyptus grandis in Uruguay. Australas Plant Pathol 32:361-366 
Camille F, Morrell JJ (2006) Decay resistance of China-fir (Cunninghamia lanceolata (Lambert) Hooker). Forest Prod J 56:29-30

Chen SF, van Wyk M, Roux J, Wingfield MJ, Xie YJ, Zhou XD (2013) Taxonomy and pathogenicity of Ceratocystis species on Eucalyptus trees in South China, including $C$. Chinaeucensis sp. nov. Fungal Divers 58:267-279

Cunningham CW (1997) Can three incongruence tests predict when data should be combined. Mol Biol Evol 14:733-740

De Beer ZW, Duong TA, Barnes I, Wingfield BD, Wingfield MJ (2014) Redefining Ceratocystis and allied genera. Stud Mycol 79:187-219

Engelbrecht CJ, Harrington TC, Alfenas A (2007) Ceratocystis wilt of cacao-A disease of increasing importance. Phytopathology 97:1648-1649

Felsenstein J (1985) Confidence intervals on phylogenetics: an approach using bootstrap. Evolution 39:783-91

Fourie A, Wingfield MJ, Wingfield BD, Barnes I (2015) Molecular markers delimit cryptic species in Ceratocystis sensu stricto. Mycol Prog 14:1-18

Glass NL, Donaldson GC (1995) Development of primer sets designed for use with the PCR to amplify conserved genes from filamentous Ascomycetes. Appl Environ Microb 6:1323-1330

Guindon S, Gascuel O (2003) A simple, fast, and accurate algorithm to estimate large phylogenies by maximum likelihood. Systematic Biol 52:696-704

Halsted BD (1890) Some fungous disease of sweet potato. New Jersey Agricultural College Experiment Station Bulletin 76:1-32

Harrington TC (2004) CABI crop protection compendium. Cabi publishing http://www.public. iastate.edu/ tcharrin/cabinfo.html 
Harrington TC, Kazmi MR, Al Sadi AM, Ismail SI (2014) Intraspecific and intragenomic variability of ITS rDNA sequences reveals taxonomic problems in Ceratocystis fimbriata sensu stricto. Mycologia 106:224-242

Hausner G, Reid J, Klassen GR (1993) On the phylogeny of Ophiostoma, Ceratocystis s.s., and Microascus, and relationships within Ophiostoma based on partial ribosomal DNA sequences. Can J Bot 71:1249-1265

Hillis DM, Huelsenbeck JP (1992) Signal, noise and reliability in molecular phylogenetic analyses. J Hered 83:189-195

Huang Q, Zhu YY, Chen HR, Wang YY, Liu YL, Lu WJ, Ruan XY (2003) First report of pomegranate wilt caused by Ceratocystis fimbriata in Yunnan, China. Plant Dis 87:1150

Huang Q, Wang YY, Zhao YY, Jiao YX, Li XF, Chen HR, Zhu YY (2008) First report of taro black rot caused by Ceratocystis fimbriata in China. Plant Pathol 57:780

Jacobs K, Bergdahl DR, Wingfield MJ, Halik S, Seifert KA, Bright DE, Wingfield BD (2004) Leptographium wingfieldii introduced into North America and found associated with exotic Tomicus piniperda and native bark beetles. Mycol Res 108:411-418

Johnson JA, Harrington TC, Engelbrecht CJB (2005) Phylogeny and taxonomy of the North American clade of the Ceratocystis fimbriata complex. Mycologia 97:1067-1092

Katoh K, Misawa K, Kuma K, Miyata T (2002) MAFFT: a novel method for rapid multiple sequence alignment based on fast Fourier transform. Nucleic Acids Res 30:3059-3066

Kile GA (1993) Plant diseases caused by species of Ceratocystis sensu strict and Chalara. In Ceratocystis and Ophiostoma: Taxonomy, Ecology and Pathogenicity (Wingfield MJ, Seifert KA \& Webber JFF eds) American Phytopathological Society Press, St Paul, Minnesota:73-183

Li J, Gao JM, Han YH, Sun YX, Huang Q (2014a) First report of Ceratocystis fimbriata-Caused wilt of Eriobotrya japonica in China. Plant Dis 98:1270 
Li J, Zhang Y, Xu KC, Yang JY, Han YH, Sun YX, Huang Q (2014b) First report of wilt of Eucalyptus caused by Ceratocystis fimbriata in China. Plant Dis. http://dx.doi.org/10.1094/ PDIS-06-14-0580-PDN

Liu L, Duan ZH, Xu MK et al (2010) Effect of monospecific and mixed Cunninghamia lanceolata plantations on microbial community and two functional genes involved in nitrogen cycling. Plant Soil 327:413-428

Mbenoun M, Wingfield MJ, Aimé D. Boyogueno B, Wingfield BD, Roux J (2014) Molecular phylogenetic analyses reveal three new Ceratocystis species and provide evidence for geographic differentiation of the genus in Africa. Mycol Prog 13:219-240

Möller EM, Bahnweg G, Sandermann H, Geiger HH (1992) A simple and efficient protocol for isolation of high molecular weight DNA from filamentous fungi, fruit bodies, and infected plant tissues. Nucleic Acids Res 20:6115-6116

Morris MJ, Wingfield MJ, de Beer C (1993). Gummosis and wilt of Acasia mearnsii in South Africa caused by Ceratocystis fimbriata. Plant Pathol 42:814-817

Naidoo K, Steenkamp ET, Coetzee MPA, Wingfield MJ, Wingfield BD (2013) Concerted Evolution in the Ribosomal RNA Cistron. PLoS One 8:e59355

Nkuekam KG, Wingfield MJ, Mohammed C, Carnegie AJ, Pegg GS, Roux J (2012) Ceratocystis species, including two new species associated with nitidulid beetles, on eucalypts in Australia. Anton Leeuw 101:217-241

Posada D, Crandall KA (1998) MODELTEST: testing the model of DNA substitution. Bioinformatics 14:817-818

Rayner RW (1970) A mycological colour chart. Commonwealth Mycological Institute Kew, Surrey and British Mycological Society

Rodas CA, Roux J, Van Wyk M, Wingfield BD, Wingfield MJ (2008) Ceratocystis neglecta sp. nov. infecting Eucalyptus trees in Colombia. Fungal Divers 28:73-84 
Roux J, Wingfield MJ, Bouillet JP, Wingfield BD, Alfenas AC (1999) A serious new wilt disease of Eucalyptus caused by Ceratocystis fimbriata in Central Africa. Forest Pathol 30:175-184

Roux J, Wingfield MJ, Bouillet JP, Winfield BD, Alfenas AC (2000) A serious new wilt disease of Eucalyptus caused by ceratocystis fimbriata in Central Africa. Forest Pathol 30:175-184

Roux J, Harrington TC, Steimel JP, Wingfield MJ (2001) Genetic variation in the wattle wilt pathogen Ceratocystis albifundus. Mycoscience 42:327-332

Roux J, Van Wyk M, Hatting H, Wingfield MJ (2004) Ceratocystis species infecting stem wounds on Eucalyptus grandis in South Africa. Plant Pathol 53:414-421

Roux J, Meke G, Kanyi B, Mwangi L, Mbaga A, Hunter GC, Nakabonge G, Heath RN, Wingfield MJ (2005) Diseases of plantation forestry trees species in Eastern Africa. S Afr J Sci 101:409-413

Roux J, Wingfield MJ (2009) Ceratocystis species: emerging pathogens of non-native plantation Eucalyptus and Acacia species. South Forests 71:115-120

Schoch CL, Seifert KA, Huhndorf S et al (2012) Nuclear ribosomal internal transcribed spacer (ITS) region as a universal DNA barcode marker for Fungi. P Natl Acad Sci USA 109:6241-6246

Swofford DL (2002) PAUP* 4.0: Phylogenetic Analysis Using Parsimony (*and other methods). Sunderland, Massachusetts: Sinauer Associates

Sy CM (1956) Studies on the control of black rot (Ophiostoma fimbriatum) of sweet potato. Acta Phytopathol Sinica 2:81-95. [In Chinese]

Tamura K, Dudley J, Nei M, Kumar S (2007) MEGA 4: Molecular Evolutionary Genetics Analysis (MEGA) software version 4.0. Mol Biol Evol 24:1596-1599

Tsopelas P, Angelopoulos A (2004) First report of canker stain of plane strees, caused by Ceratocystis fimbriata sp. platani in Greece. Plant Pathol 53:531

Upadhyay HP (1981) A monograph of Ceratocystis and Ceratocystiopsis. University of Georgia Press Athens 
Van Wyk M, Roux J, Barnes I, Wingfield BD, Liew ECY, Assa B, Summerell BA et al (2004) Ceratocystis polychroma sp. nov., a new species from Syzygium aromaticum in Sulawesi. Stud Mycol 50:273-282

Van Wyk M, Al Adawi AO, Khan IA, Deadman ML, Al Jahwari AA, Wingfield BD, Ploetz R. Wingfield MJ (2007a) Ceratocystis manginecans sp. nov., causal agent of a destructive mango wilt disease in Oman and Pakistan. Fungal Divers 27:213-230

Van Wyk M, Pegg G, Lawson S, Wingfield MJ (2007b) Ceratocystis atrox sp. nov. associated with Phoracantha acanthocera infestations on Eucalyptus grandis in Australia. Australas Plant Path $36: 407-414$

Van Wyk M, Wingfield BD, Clegg PA, Wingfield MJ (2009) Ceratocystis larium sp. nov., a new species from Styrax benzoin wounds associated with incense harvesting in Indonesia. Persoonia $22: 75-82$

Van Wyk M, Roux J, Kamgan NG, Wingfield BD, Wingfield MJ (2012) Ceratocystis eucalypticola sp. nov. from Eucalyptus in South Africa and comparison to global isolates from this tree. IMA Fungus 3:45-58

White TJ, Bruns T, Lee S, Taylor J (1990) Amplification and direct sequencing of fungal ribosomal RNA genes for phylogenetics. In: Innis MA, Gelfand DH, Sninsky JJ, White TJ (eds) PCR Protocols: a guide to methods and applications. Academic, New York 230-257

Wilken PM, Steenkamp ET, Wingfield MJ, De Beer ZW, Wingfield BD (2013) Draft nuclear genome sequence for the plant pathogen, Ceratocystis fimbriata. IMA Fungus 4:357-358

Wingfield MJ, Seifert KA, Webber JF (1993) Ceratocystis and Ophiostoma: Taxonomy, Ecology and Pathogenicity St Paul, Minnesota: American Phytopathological society Press

Wingfield MJ, De Beer ZW, Slippers B, Wingfield BD, Groenewald JZ, Lombard L, Crous PW (2012) One fungus, one name promotes progressive plant pathology. Mol Plant Pathol $13: 604-613$ 
Xie YJ (2011) Research progress on Eucalyptus breeding and its strategy in China. World Forestry Res 24:50-54. [In Chinese]

Xu B, Zheng, XH, Guo WX, Zhou XP, He P (2011) First report of pomegranate wilt caused by Ceratocystis fimbriata in Sichuan Province. Plant Dis 95:776

Zipfel RD, De Beer ZW, Jacobs K, Wingfield BD, Wingfield,MJ (2006) Multigene phylogenies define Ceratocystis and Grosmannia distinct from Ophiostoma. Stud Mycol 55:75-79

Zhou XD, Wingfield MJ (2011) Eucalypt diseases and their management in China. Australas Plant Path 40:339-345 